\title{
Articles
}

\section{Refugee Burden-Sharing: A Modest Proposal}

\author{
Peter H. Schuck ${ }^{\dagger}$
}

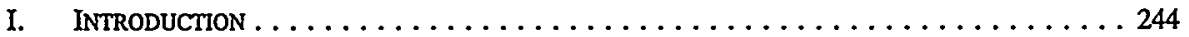

II. The Current Regme for Protecting Refugees $\ldots \ldots \ldots \ldots \ldots \ldots \ldots \ldots$

III. The Comprehensive Plan of Action $\ldots \ldots \ldots \ldots \ldots \ldots \ldots \ldots \ldots \ldots \ldots$

IV. Four Remedial Strategies $\ldots \ldots \ldots \ldots \ldots \ldots \ldots \ldots \ldots \ldots \ldots \ldots \ldots \ldots \ldots \ldots$

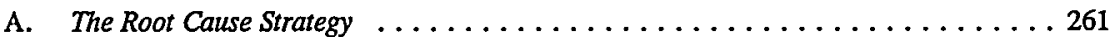

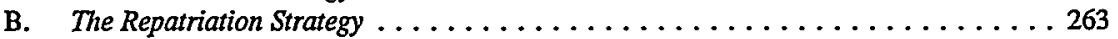

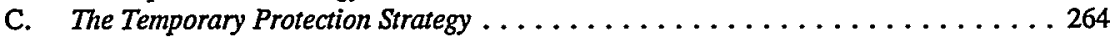

D. Permanent Resettlement ........................... 268

V. THE Proposal: Proportional BURden-Sharing $\ldots \ldots \ldots \ldots \ldots \ldots \ldots \ldots \ldots \ldots \ldots \ldots$

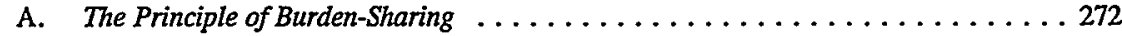

B. The Needs Assessment Process . . . . . . . . . . . . . . . . . . . . 277

C. The Criteria for Allocating the Protection Burden .............. 279

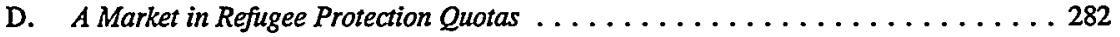

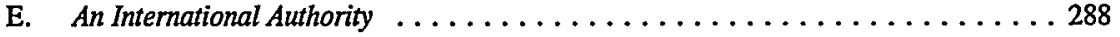

VI. A Response to (ANTICIPATEd) CRTICS $\ldots \ldots \ldots \ldots \ldots \ldots \ldots \ldots \ldots \ldots \ldots \ldots$

A. The Unworkability Objection ........................ 289

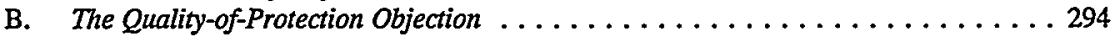

C. The Commodification Objection ...................... 296

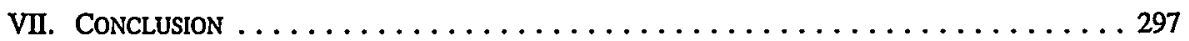

$\dagger \quad$ Simeon E. Baldwin Professor of Law, Yale Law School; John Marshall Harlan Distinguished Visiting Professor of Law, New York Law School (Spring 1997). The author received useful comments on an earlier version of this Article from faculty workshops at the Yale, McGeorge, New York, and Western New England law schools, and especially from Professors Lenni Benson, Joan Fitzpatrick, James Hathaway, Paul Kahn, Hiroshi Motomura, James Nafziger, W. Michael Reisman, Peter Spiro, and Myron Weiner. Wendy Weiser, Yale Law School class of 1996, provided excellent research assistance. 


\section{INTRODUCTION}

The world is awash in refugees. ${ }^{1}$ According to the most recent estimates, more than fifteen million individuals are already outside their countries and in need of international protection and assistance. ${ }^{2}$ This population, already immense, is growing steadily and remorselessly with the proliferation of refugee-producing and migration-facilitating conditions: political repression, armed conflict, civil strife, environmental disaster, famine, social and economic disintegration, wretched governmental policies, and improvements in communications and transportation opportunities. ${ }^{3}$ Refugee emergencies have become so endemic that the rhetoric of crisis today is as likely to numb as it is to energize. ${ }^{4}$

The current legal and political arrangements for managing refugee flows were established to manage European cross-border refugee flows during the post-World War II era. The cause of these flows became much more varied as time went on, their locus shifted during the 1960s, 1970s, and 1980s to other

1. The word "refugees," of course, carries several different meanings. In this Article, I shall generally use the word in its broadest connotation to characterize individuals who have fled their country for one reason or another and believe that they cannot or should not return to it in the near future, although they may hope to do so if conditions permit. In this usage, the category is narrower than both "migrants" (whom I think of simply as people on the move) and "immigrants" (who have left their country intending to reside permanently in some other country). It is much broader, however, than the technical legal category of refugee defined in the Convention Relating to the Status of Refugees, July 28, 1951, art. 1, para. A, 189 U.N.T.S. 137, 152 [hereinafter 1951 Refugee Convention], and in U.S. immigration law, see 8 U.S.C. § 1101(a)(42) (1994). When I write of refugees in what follows, I mean to use the term in its broader, nonlegal connotation except when the context indicates the contrary.

2. World Refugee Statistics, WORLD REFUGEE SURVEY: 1995 IN REVIEW (1996), at 3, 4 tbl.1. Many millions more are internally displaced. See id. at 6 tbl.3. Other estimates vary. The New York Times reports a February 1995 count by the United Nations High Commissioner for Refugees (UNHCR) estimating that 23 million refugees had crossed borders and another 26 million were displaced in their own countries. According to this report, " 1 in every 115 people on earth is now on the run or in some kind of exile." Barbara Crossette, This Is No Place Like Home, N.Y. TimEs, Mar. 5, 1995, at D3. On the other hand, Immigration Review reports that UNHCR recognizes 14.4 million refugees, down $25 \%$ from the 18.2 million classified as refugees in 1993. 24 IMMMGR. REV., Winter 1996, at 7, 7. I shall not attempt to reconcile these figures; even the lowest estimates present an immense human tragedy and awesome policy challenge.

3. A recent empirical study of the sources and causes of refugee flows to the United States indicates that these factors have changed significantly in the last quarter century. Wars and political persecution (other than from ethnic conflicts) are less important causes of refugee flows than they were in 1969. Although the number of countries and conflicts generating refugee flows has changed little since then, what has principally changed is the number of refugees per conflict, which in turn reflects increasing levels of violence per conflict due to the growth in antipersonnel mines and small arms weapons. The rise in the number of refugees per conflict remains even after one controls for population growth and easier transportation. For purposes of the present discussion, the most important implications of the increased violence and the kinds of weapons employed are that they have multiplied the total refugee flow and made repatriation of refugees much more difficult. See Myron Weiner, Bad Neighbors, Bad Neighborhoods: An Inquiry into the Causes of Refugee Flows, 1969-1992, in MIGRANTS, REFUGEES, AND FOREIGN POLICY: U.S. AND GERMAN POLICIES TOWARD COUNTRIES OF ORIGIN (Rainer Munz \& Myron Weiner eds., forthcoming 1997).

4. The notion of "compassion fatigue" was coined during the 1970 s to reflect this psychological reality. Only this can account for the current passivity of the Clinton administration with respect to the appalling refugee crisis in eastern Zaire. See Iain Guest, How and When To Intervene for Humanity, CHRISTIAN SCI. MONITOR, Dec. 2, 1996, at 19 (noting that American failure to define policy in Zaire leaves desperate refugees trapped). 
regions, notably Africa, south and southeast Asia, the Middle East, and the Caribbean, and internally displaced individuals became more numerous than the border-crossing refugees. ${ }^{5}$ By the 1980 s, Europe had come to think of the refugee burden as more of a problem for the Third World and the United States than for itself. Protected from large-scale refugee movements by an impregnable Iron Curtain in the east, Europe seemed relatively immune to the threat.

It is no longer possible to entertain this comforting illusion. With the dissolution of the Soviet Union, Germany's reunification, the militarization of bitter ethnic conflicts in the Balkans, and the failure of many former European colonies to establish viable political and economic systems, refugees are once again pouring into the very heart of Europe. Moreover, new migration routes, facilitated by cheap transportation and intricate social networks, are bringing migrants to Europe (and thence to the United States) from Asia, Africa, and the Pacific archipelago. ${ }^{6}$ Although few of these migrants are likely to meet the legal qualifications for Convention refugee status, ${ }^{7}$ many of them nevertheless seek some form of temporary or permanent protection and must be processed in one or another European state unitil their status can be determined-with the attendant fiscal, social, and political burdens on the receiving state that such processing ordinarily entails. ${ }^{8}$ Europe thus joins the Third World, North America (the United States and Canada), ${ }^{9}$ and the other traditional receiving

5. On the growing predominance of the internally displaced, see Weiner, supra note 3 .

6. See Raymond Bonner, New Road to West for Illegal Migrants, N.Y. TimES, June 14, 1995, at

7. The Refugee Convention defines a refugee as a person with a "well-founded fear of being persecuted for reasons of race, religion, nationality, membership in a particular social group, or political opinion, is outside the country of his nationality and is unable or, owing to such fear, is unwilling to avail himself of the protection of that country." 1951 Refugee Convention, supra note 1, art. 1, para. A(2). This does not cover the bulk of migrants fleeing the conditions listed in the first paragraph of this Article.

8. The methods for processing refugees in Europe were harmonized in the Dublin Convention and the Second Schengen Agreement. Convention Applying the Schengen Agreement of 14 June 1985 Between the Governments of the Benelux Economic Union, the Federal Republic of Germany, and the French Republic on the Gradual Abolition of Checks at Their Common Borders, June 19, 1990, 30 I.L.M. 84 [hereinafter 1985 Schengen Agreement]; Convention Determining the State Responsible for Examining Applications for Asylum Lodged in One of the Member States of the European Communities, June 15, 1990, 30 I.L.M. 427 [hereinafter 1990 Dublin Convention]. The 1990 Dublin Convention establishes uniform procedures for processing asylum applicants, and the 1985 Schengen Agreement contains rules for determining one "responsible state" to process each application. See James C. Hathaway, Harmonizing for Whom? The Devaluation of Refugee Protection in the Era of European Economic Integration, 26 CORNELL INT'L L.J. 719, 722-28 (1993); Gerald L. Neuman, Buffer Zones Against Refugees: Dublin, Schengen, and the German Asylum Amendment, 33 VA. J. INT'L L. 503, 506-09 (1993). By relegating asylum seekers to one asylum application and adjudication in Europe, these agreements are likely to decrease the level of refugee protection. The United States and Canada are planning to enter into a similar "country of first arrival" agreement. See Canada, U.S. Release Joint Draft Agreement on Refugee Claims, 72 INTERPRETER RELEASES 1614 (1995).

9. Several recent developments in the United States might increase the pressures here, quite apart from the more secular growth in refugee movements throughout the world that inevitably affect the United States. These developments include the amendment of the statutory "refugee" definition to include persecution for resistance to coercive population control methods, see Illegal Immigration Reform and Immigrant Responsibility Act of 1996 (IIRIRA), Pub. L. No. 104-132, § 601, 110 Stat. 1214 (amending 8 U.S.C. \& 1101(a)(42)), the granting of some of the rapidly growing number of asylum applications from Mexicans, see Sam Verhovek, In a Shift, U.S. Grants Asylum for 55 Mexicans, N.Y. Tmes, Dec. 1, 1995, 
regions in facing the prospect of additional flows of migrants claiming protection through the international refugee system, broadly defined.

Virtually all discussions of refugee law and policy focus on the acute vulnerability of refugees. These commentators seek ways to alleviate refugees' sufferings, either by fulfilling or extending the protections to which they are entitled or by eliminating the political conditions that impel them to flee from their homelands. The reason for this focus on the refugees themselves is as obvious as it is sound and humane: Refugees present egregious cases of injustice and compelling claims for some form of international protection. Their claims are compelling not so much because they often live in conditions of poverty, unemployment, rude shelter, and mistreatment. After all, these are the conditions of daily life for most other human beings unfortunate enough to have been born into the wrong social class in the wrong place at the wrong time. These conditions are also those in which most refugees lived before their flight made them objects of international law's concern. Instead, what marks refugees off for particular solicitude is their radical, enforced dislocation and isolation and their uncertain legal status as aliens. They are of special humanitarian concern because they were compelled to abandon the only protections and solaces that can render the harsh vicissitudes of life endurable: the assistance (however minimal) of their own governments and the social supports of their customary communities.

The perspective of this Article, however, is quite different. Rather than focus on the suffering that refugees endure or the root causes of their flight, I take these remorseless facts as tragically given. I emphasize instead the burdens that the sudden, massive refugee flows that are now endemic impose on states. I do so not because these burdens are more than the international order, taken as a whole, can or should bear (they are not) but because I am convinced of the following three propositions. First, the emerging state responses to these burdens are seriously jeopardizing the viability of any meaningful regime of international human rights protection. Second, any realistic solution to this problem must somehow forestall these responses by easing these burdens in exchange for a set of obligations that states are more willing to accept and implement. Third, this can only be accomplished by distributing obligations more widely and fairly among states over time.

Doubtless, my effort to salvage a meaningful human rights regime from the carcass of state sovereignty will seem rather odd to many well-informed commentators on refugee law and policy in the academy and in the field. They often maintain that state sovereignty constitutes perhaps the chief threat and

at $\mathrm{A1}$ (citing increase in applications from 122 in 1990 to 6397 in 1993 to 9304 in 1995, while grants increased from zero in 1993 to 54 in 1995), and the much-publicized grant of asylum to a woman from Togo based on her fear of clitoridectomy, see In re Kasinga, Interim Dec. No. 3278 (B.I.A. 1996); Celia W. Dugger, Board Hears Asylum Appeal in Genilal-Mutilation Case, N.Y. TIMES, May 3, 1996, at B5 (estimating that more than 85 million women in world are subject to clitoridectomy). On the other hand, other provisions of IIRIRA adopted new procedures that are intended to restrict the availability of asylum. See IIRIRA § 601 (amending 8 U.S.C. $\S 1158$ ). 
impediment to the fulfillment of human rights goals. To them, state sovereignty is the problem, not the solution.

This view is certainly plausible. After all, nation-states are today the principal designers and executors of human rights violations. They also encourage, abet, condone, or at least fail to prevent many human rights violations committed by ostensibly private groups. Finally, the principle of state sovereignty often delegitimates and stymies proposed interventions by states and supranational groups into the offending state's territory-interventions that might prevent or rectify violations occurring entirely within national borders. In each of these ways, the nation-state has indeed impeded and confounded human rights goals, just as its critics suggest. ${ }^{10}$

This line of argument is true as far as it goes, but it does not go nearly far enough. For it is also true that for the foreseeable future, genuine human rights protections-particularly the protection of refugees-can only be enforced and implemented by sovereign states or by other entities such as supranational agencies and nongovernmental organizations (NGOs) working with their assistance or sufferance. This is a brutal reality of which any practicable, meaningful reform proposal must take full account. To ignore or deny it is to engage in a dangerous fatuity.

But the link between sovereignty and protection is more than a regrettable necessity. While malefactors have committed great crimes in the name of state sovereignty, the nation-state has also been an essential, powerful force for justice. The mature nation-state is a unique formation conceived through communal imagination, cemented by history, fueled by political ideology, and equilibrated by institutions. Its combination of scale, power, predictability, and normativity enable it to generate levels of self-sacrifice and coordinated action in the common interest of which other groupings, whether larger or smaller, seem incapable.

But however one appraises the overall relationship between nation-states and human rights, the analysis and proposal that follow are constructed on a premise that few knowledgeable observers of the current refugee regime can seriously dispute. My premise is that the current refugee regime is "broke"-in the limited but important sense that it fails to afford adequate protection to the enormous and growing number of people fleeing from what seem to be, and often are, intolerable conditions-and that it needs fixing. This is not to deny

10. For recent examples of sovereignty skeptics, see JEAN-MARIE GUEHENNO, THE END OF THE NATION-STATE (Victoria Elliot trans., 1995); DAVID JACOBSON, RIGHTS ACROSS BORDERS: IMMIGRATION AND THE DECLINE OF CITIZENSHIP (1996); YASEMIN N. SOYSAL, LMMTS OF CITIZENSHIP: MIGRANTS AND Postnational MeMbership In EuRope (1994); Claudio Grossman \& Daniel D. Bradlow, Are We Being Propelled Towards a People-Centered Transnational Legal Order?, 9 AM. U. J. INT'L L. \& POL'Y 1 (1993); Aristide R. Zolberg, Changing Sovereignty Games and International Migration, 2 IND. J. GLOBAL LEGAL STuD. 153 (1994); see also David A. Martin, Effects of International Law on Migration Policy and Practice: The Uses of Hypocrisy, 23 INT'L MiGRATION REv. 547, 548 (1989) (citing sources suggesting that doctrine of sovereign discretion over immigration is fundamentally erroneous). A related genre of commentary on sovereignty emphasizes its transcendence by economics-driven regionalism. See, e.g., KENICHI OHMAE, THE END OF THE NATION STATE: THE RISE OF REGIONAL ECONOMIES (1995). 
the many important and often heroic responses that the international community has mounted to address human rights emergencies. Indeed, I describe one such response, the Comprehensive Plan of Action and Orderly Departure Program in Southeast Asia (CPA), in some detail. It is simply to say that much more needs to be done as these emergencies continue to proliferate.

This Article proceeds in several parts. In Part II, I discuss some of the reasons why the current refugee protection regime is inadequate. In Part III, I summarize the CPA experience, the most important example of a negotiated refugee burden-sharing arrangement, which suggests both the value of international burden-sharing quotas and the need to create a more reliable, effective structure for prescribing and administering them.

In Part IV, I consider four broad strategies for improving refugee protection. In the order of their abstract desirability, they are: (1) eliminating the root causes of refugee flows; (2) prompt repatriation of refugees; (3) temporary protection of refugees; and (4) permanent resettlement of refugees in third countries. ${ }^{11}$ I conclude (with virtually all other commentators) that each of these is problematic and that the practical realities of refugee crises and international refugee politics often require resort to the strategies of temporary protection and permanent resettlement because the more desirable ones are simply not available.

In Part V, I describe my proposal, which is intended to ameliorate some, ${ }^{12}$ but certainly not all, of the most important inadequacies in the current system. Details aside, the proposal consists of two main elements. First, a group of states would agree to observe a strong norm of proportional burden-sharing for refugees, would seek to induce other states to join the group, and would arrange for an existing or newly-established international agency to assign to each participating state a refugee protection quota. A state's quota would commit it to assure temporary protection or permanent resettlement for a certain number of refugees over a certain time period. Second, the participating states would then be permitted to trade their quotas by paying others to fulfill their obligations. As noted immediately below, states would participate in the quotacum-market system voluntarily, albeit under the influence of their more powerful neighbors. Accordingly, the system should require only limited regulation by the agency. As discussed in Section V.E, its chief responsibilities would be to administer the system, including the quotas and the flow of information about refugees, and to ascertain whether the requisite protection is actually being delivered.

I propose that this scheme be entirely consensual on the part of the participating states and that it be established on a regional or even a subregional

11. As noted below, "temporary" protection often turns out to be permanent. On the other hand, refugees receiving "permanent" resettlement might-should conditions in their country of origin change-later wish or (if they are not yet citizens) be required to repatriate. See infra notes 77-78 and accompanying text.

12. For example, it would deal with the growing problem of the internally displaced. See Weiner, supra note 3. 
basis, rather than on a global one. These states would define the refugees who might look to them for protection according to agreed-upon criteria. For example, the criteria might prefer refugees from countries of origin located in the region, refugees in first-asylum states located there, or refugees from countries with historical ties to participating states.

A regionally-structured system would possess several important advantages over a more global one. It could exploit a tradition of regional responsibility for localized refugee flows and solutions, the greater commonality of interests and values that regions tend to share, and the more intense patterns of interaction that they exhibit. It would minimize the psychological, fiscal, and other costs of having to relocate refugees over long distances and of locating them farther from their homes. Its limited size and consensual character would also make it administratively more manageable. As with other groups seeking gains from trade, however, participating states would have an incentive to expand the membership over time if the scheme proved successful..$^{13}$

I also discuss in Part $\mathrm{V}$ why this unusual burden-sharing scheme might actually be politically acceptable and practically workable. Such a happy outcome, however, is far from clear. Under the existing regime, after all, states that are not states of origin or of first asylum are entirely free to join in, or refrain from, refugee protection efforts, as their interests dictate. Why then would they choose to surrender that freedom of action and accept a burdensharing obligation that is likely to be costly, risk domestic political tensions, and probably ratchet upwards over time?

Some states will probably reject such an obligation out of hand; they will point out that they neither generate refugee flows nor are likely to receive them. They may also point to the fact that the kind of massive refugee flows that have occurred in Rwanda and the former Yugoslavia are the exception, not the rule. The larger, wealthier, and more stable states can often absorb smaller, more gradual refugee movements without resorting to extraordinary measures.

Even these states, however, might be attracted to burden-sharing for the same reason that many individuals are attracted to catastrophic health insurance: States may rationally prefer to incur a small and predictable protection burden now in order to avoid bearing large, sudden, unpredictable, unwanted, and unstoppable refugee inflows in the future. They might prefer a system that created strong incentives for more states to support temporary protection of refugees, largely in the Third World, over the current one, which generates

13. One possible objection to organizing this proposal on a regional basis-that it would further balkanize international relationships that are already divided along economic, racial, and ethnic lines for which regions are proxies-seems weak. Regional bloc formation reflects large geopolitical and global economic forces. Moreover, it is gradually giving way to a more integrated system, as suggested by the recent expansions of NAFTA, MERCOSUR, NATO, the EU, and other groupings that were initially more geographically limited than they are now, as well as by proposals to extend them further in the future. To the extent that regional arrangements entail problems, my scheme is not intended to solve them. By emphasizing the interdependence and mutual interests of different regions, however, it might even improve their relationships, as mutually beneficial market transactions tend to do. The issue of discrimination by states in the trading of protection quotas is discussed in infra text accompanying notes 148-49. 
strong pressures for an even more dreaded (from their perspective) form of relief: permanent resettlement.

As the world grows smaller and more interconnected, and as an increasing number of refugees can more easily reach more places and claim protection there, such "refugee crisis insurance" might well be a "good buy"-perhaps even for relatively insular states. By introducing a market in quota obligations, the scheme would permit even greater flexibility. For many states, then, this burden-sharing scheme would be fairer and more rational than the status quo-especially if, as I propose, it were established on a regional basis. So, at least, I shall argue.

Part V concludes by discussing how such a scheme would be enforced. Briefly, I suggest that while the scheme would be administered and to some extent enforced by an international agency, it is the states with the greatest interest in a better refugee protection system-those in North America and Western Europe-that would have the strongest incentives to deploy the various carrots and sticks of international diplomacy at their disposal (trade benefits, other forms of assistance, security guarantees, etc.) in order to secure both initial agreement and subsequent compliance.

The United States has compelling reasons to seize the initiative on this issue. As the only remaining superpower and the leading funder of the existing international refugee system, it has the greatest stake in assuring a just and stable world order. The Bosnian tragedy revealed a vacuum of leadership in European refugee crises that only the United States can fill. Finally, the United States continues to be vulnerable to its own sudden refugee flows from the Caribbean, which it has experienced from time to time since 1980.

So far as I know, this proposal is a novel one-although it resembles in some respects an approach adumbrated by Professor James C. Hathaway several years ago, ${ }^{14}$ and its quotas feature seeks to build on the embryonic burden-sharing norm that the CPA experience, detailed in Part III, exemplified. Because the proposal will certainly be controversial in the refugee-policy community, Part VI defends it against a variety of anticipated objections, particularly to its market element, which is bound to arouse the most opposition. At the outset, however, I wish to emphasize a point that should inform one's reaction to the entire analysis. Although the proposal entails many problems, virtually all of those problems already exist, sometimes to an even greater degree, in the current system. For this reason, I urge the reader to keep the "compared to what" question firmly in mind as she ponders these problems.

\section{The CuRRent Regime For Protecting Refugees}

The existing system of refugee protection is almost universally criticized

14. James C. Hathaway, Reconceiving Refugee Law as Human Rights Protection, 4 J. REFugeE STUD. 113, 126-28 (1991) (proposing international protection system that removes national interdiction schemes and directly involves international supervisory agency in protective measures taken pending viability of safe return to state of origin). 
by those individuals and organizations most committed to human rights goals, ${ }^{15}$ and by governments that are affected by its functioning. The bill of particulars in the various indictments converge in many respects. All commentators recognize that the system was designed in the post-World War II era to deal with a predominantly European displaced population facing prospects quite different from those confronting today's refugees. Modern globalization of the world economy, the revolutions in transportation and communications, and the dissolution of colonial empires into a plethora of weak and often oppressive states-changes so consequential for the magnitude and character of contemporary refugee flows-all lay in the future. ${ }^{16}$

The system that developed is one in which each state of first asylum must determine the status of the claimant-in particular, whether she qualifies as a refugee under the 1951 Convention Relating to the Status of Refugees. ${ }^{17}$ If so, she may be entitled as a matter of international, and perhaps domestic, law to the panoply of rights that the Convention accords refugees. ${ }^{18}$

From the perspective of refugees seeking protection, this system suffers from a number of serious flaws. Since all of these flaws have already received much attention and extensive critical analysis from refugee advocates, international organizations, and scholars of international human rights law, I shall discuss them only briefly. The core legal concepts embedded in the refugee definition-persecution on account of race, religion, national origin, political opinion, or membership in a particular social group-are expansive and ambiguous enough to have engendered enormous uncertainties when they are applied to particular cases. On the other hand, these concepts are quite narrow relative to the diverse circumstances and motives that may prompt individuals to leave their countries in haste and in vulnerable condition. ${ }^{19}$

15. See, e.g., Guy S. Goodwin-Gill, Refugees: The Functions and Limits of the Existing Protection System, in HUMAN RIGHTS AND THE PROTECTION OF REFUGEES UNDER INTERNATIONAL LAW 149, 165-73 (Alan E. Nash ed., 1987); Gil Loescher, The International Refugee Regime: Stretched to the Limit?, 47 J. INT'L AFF. 351, 376-77 (1994).

16. See, e.g., Myron Weiner, The Global Migration Crisis: Challenge to States and to HUMAN RIGHTS (1995) (presenting recent and comprehensive analysis of these developments).

17. See 1951 Refugee Convention, supra note 1.

18. On international refugee law, see generally GUY S. GOODWIN-GILL, THE REFUGEE IN INTERNATIONAL LAW (1983); ATLE GRAHL-MADSEN, THE STATUS OF REFUGEES IN INTERNATIONAL LAW (1972). On domestic asylum law, see generally 6 CHARLES GORDON ET AL., IMMIGRATION LAW AND PROCEDURE § 137 (1996).

19. Some conventions have adopted broader refugee definitions. Conclusion 3 of the Cartegena Declaration classifies as refugees persons "[who] have fled from their country because their life, safery, or liberty have been threatened by widespread violence, foreign aggression, domestic conflict, massive violation of human rights or other situations that have seriously disturbed public order." Cartegena Declaration, quoted in Annual Report of the Inter-American Commission on Human Rights, 1984-85, Organization of American States, OEA/Ser.L/V/II.66/Doc.10, rev.1, at 179-82 (1985). The Organization of African Unity added the following language to the definition of refugee:

every person who, owing to external aggression, occupation, foreign domination or events seriously disturbing public order in either part or the whole of his country of origin or nationality, is compelled to leave his place of habitual residence in order to seek refuge in another place outside his country of origin or nationality.

OAU Convention Governing the Specific Aspects of Refugee Problems in Africa, Sept. 10, 1969, art. I, para. 2, 1001 U.N.T.S. 45, 47; see also supra note 9 (discussing amendment of U.S. refugee definition to 
The refugee protection system, however, has less to do with the legal niceties of the Refugee Convention than with the political prerogatives of sovereign states. Each state judges for itself whether a particular migrant or group of migrants who reaches its territory or seeks resettlement there will receive that, or any, relief. Each state, moreover, possesses powerful disincentives to provide relief, especially on its own territory. Such relief is costly to provide; at a minimum, it includes food, clothing, shelter, and information. If the state does not allow the migrants to come and go as they please, it must keep them in custody or under close surveillance. If they remain in custody in close quarters and enforced idleness, the risks of violence, crime, and other social pathologies are correspondingly great. Although refugees are often kept in the most squalid conditions, those conditions may nevertheless be superior to those in which most citizens of the receiving state live.

In any event, the admission and maintenance of even small numbers of refugees over long periods of time are almost certain to occasion bitter political opposition within the receiving state, especially if the refugees are permitted to compete for scarce jobs. The presence of refugee populations can create serious foreign policy embarrassments. In sufficient numbers and under certain conditions, the mere presence of refugees can constitute a genuine national security threat to the receiving state. They may prompt domestic rioting, ethnic violence, and the destabilization, perhaps even overthrow, of the regime. ${ }^{20}$ In this sense, refugee protection is not simply a human rights issue; it can also be a matter of geopolitical significance affecting the security of the international order.

Nor are these risks equally distributed across the globe. To the contrary, this distribution is decidedly lumpy. Until the demise of the former Soviet Union and the outbreak of hostilities in the former Yugoslavia, Europe had generated and received relatively few refugees for decades. Even today, most refugee flows occur in Africa and southern Asia, and the brunt of refugee burdens by far is borne by neighboring states in those regions.

A state inclined to comply with only the letter of the Refugee Convention is not obliged to afford much protection to the migrant. The duty of nonrefoulement-the obligation not to return a refugee to conditions of persecution-is clear enough, but most of the other rights-defining provisions

include those fleeing coercive population control).

20. The armed attacks by exiled Rwandan Hutu militias against Tutsis in Zaire is a recent example, see, e.g., Nicholas D. Kristof, Rwandans, Once Death's Agents, Now Its Victims, N.Y. Times, Apr. 13, 1997, at A1 (noting continued refugee crises and persistent ethnic battles among exiles), as is the suspected killings of refugees by Zairian rebels, see Raymond Bonner, New Refugee Crisis Builds in Zaire, N.Y. TMES, May 14, 1997, at A8 (reporting that Kabila's rebels may have participated in killings). Unfortunately, there are many others. See, e.g., Cuban Refugees Riot in Cayman Islands Camp, N.Y. TmMS, Apr. 18, 1995, at A7; Edward A. Gargan, 200 Vietnamese Refugees Flee Detention Camps in Hong Kong, N.Y. TIMES, May 11, 1996, at A4 (reporting on riots, arson, hostage-taking, escapes); Douglas Jehl, Israeli Barrage Hits U.N. Camp in Lebanon, Killing at Least 75, N.Y. TimES, Apr. 19, 1996, at A1; Eric Schmidt, Cuban Refugees Riot in Panama, N.Y. TMmEs, Dec. 9, 1994, at A1; Philip Shenon, Khmer Rouge Said To Harass Refugees, N.Y. TIMES, Mar: 26, 1992, at A3 (discussing Khmer Rouge attacks on refugee camps in Thailand and Cambodia). 
of the Convention contain qualifying phrases and other limitations designed to protect the interests and prerogatives of the receiving state. ${ }^{21}$

It appears, however, that most states are not so inclined. For them, freeriding appears to be the rational strategy in the area of refugee protection. This means accepting as few refugees as possible in the hope that others will assume the burdens of resettling or otherwise dealing with them. The pursuit of a freerider strategy is constrained only by whatever pressures can be exerted by domestic refugee advocates, international human rights organizations, and other states that can deploy a variety of carrots or sticks.

The primary institutional advocates for refugees within the system, and the most insistent voices calling for state compliance with its norms, are the United Nations High Commissioner for Refugees (UNHCR) and the many secular and religious nongovernmental organizations (NGOs) working in the refugee field. Yet both UNHCR and the NGOs are chronically underfunded relative to their growing protection responsibilities, and they are vulnerable to political attack by the receiving states on whom they must rely for their operating authority, budget, cooperation, and legitimacy. In reality, these forces compromise them at every turn. Under the exceedingly difficult circumstances in which UNHCR and the NGOs must usually work, the wonder is that they perform as effectively as they do.

For these and other reasons, refugee protection has proven to be woefully inadequate-a conclusion to which countless human victims bear grim and silent witness. This inadequacy is especially apparent during refugee emergencies such as those in southeastern Asia during the 1970s and 1980s, and Africa and the former Yugoslavia in the 1990s. Here, however, I wish to emphasize one systemic, institutional failure that I believe contributes substantially to all of the others: the failure of refugee burden-sharing among states. If meaningful reform of the refugee protection system is to occur, it must start here.

The problem is simpler to state than to solve. Although the entire international community ought to shoulder the burdens of dealing with massive refugee flows, only a relatively small number of nations and regions actually do so. Some of those least capable of bearing these burdens have in fact carried a disproportionately large share of them. This is most strikingly true of some African states that often serve as countries of first asylum for many of the most wretched refugees. Conversely, some of the states that are most capable of incurring refugee burdens have stood on the sidelines watching.

No strong norm of refugee burden-sharing currently exists in international law or practice. This is not to say that the appeal of such a norm has gone

21. For instance, refugee seamen are accorded the right to "sympathetic consideration to their establishment on [a contracting state's] territory." 1951 Refugee Convention, supra note 1, art. 11. With respect to movable and immovable property, see id. art. 13, and with respect to rights of self-employment, see id. art. 18, refugees are to receive "treatment as favourable as possible," $i d$. arts. 13,18. Refugees are accorded the right to freedom of movement "subject to any regulations applicable to alien generally in the same circumstances." Id. art. 26. Refugees "lawfully in [a state's] territory" may not be expelled "save on grounds of national security or public order." Id. art. 32 . 
unremarked. In recent years, a number of commentators have called for the creation or recognition by the international community of a norm of equitable burden-sharing. ${ }^{22}$ Some have inferred a principle of international solidarity from more abstract principles of justice or have discerned such a principle from existing international instruments ${ }^{23}$ from which the norm of equitable burdensharing of refugees might be derived as a logical and normatively desirable corollary. ${ }^{24}$ Such inferences, however, are more in the nature of moral exhortation and prudential argument than expositions of authoritative legal principles. ${ }^{25}$ In practice, there have been very few instances of large-scale burden-sharing arrangements designed to expand rather than restrict refugee protection. ${ }^{26}$ The most important example is the CPA. ${ }^{27}$

\section{The COMPREHENSIVE Plan of ACtion}

The CPA resettlement program provides a useful study of the conditions under which burden-sharing can succeed. They developed and were refined over an extended period of time, and involved intensive bilateral and multilateral negotiations conducted in a crisis atmosphere in which national selfinterest was the main driving force and jerry-built, practical solutions were the

22. See, e.g., G.J.L. Coles, Problems ARISing From LARGE NUMBERS OF AsYLUM-SeEkers: A STUDY OF PROTECTION ASPECTS 36-40 (1986); GERASSIMOS FOURLANOS, SOVEREIGNTY AND THE INGRESS OF ALIENS 155, 159-61 (1986); Howard Adelman, Obligation and Refugees, in HUMAN RIGHTS AND THE PROTECTION OF REFUGEES UNDER INTERNATIONAL LAW, supra note 15, at 73, 73-87; James C. Hathaway \& R. Alexander Neve, Making Intemational Refugee Law Relevant Again: A Proposal for Collectivized and Solution-Oriented Protection, 10 HARV. HUM. RTS. J. (forthcoming 1997).

23. There are a number of such instruments. See, e.g., U.N. CHARTER art. 49 (declaring that members "shall join in affording mutual assistance in carrying out the measures decided upon by the Security Council"); 1951 Refugee Convention, supra note 1, art. 150 (considering "that the grant of asylum may place unduly heavy burdens on certain countries, and that a satisfactory solution of a problem of which the United Nations has recognized the international scope and nature cannot therefore be achieved without international cooperation"); 3 THE COLLECTED TRAVAUX PREPARATOIRES OF THE 1951 GENEVA CONVENTION RELATING TO THE STATUS OF REFUgeEs 114 (Alex Takkenberg \& Christopher C. Tahbaz eds., 1990) (recommending "that Governments continue to receive refugees in their territories and that they act in concert in a true spirit of international co-operation in order that these refugees may find asylum and the possibility of resettlement"); infra Section V.

24. See, e.g., GoodwiN-GIL, supra note 18, at 101-26, 215-34.

25. Howard Adelman, for example, argues for burden-sharing in the following terms:

[U]nless states that claim to hold to this principle of justice collectively share the burden of extending that principle to individuals outside the orbit of any state and lacking protection, the situation will tend to destabilize, particularly in those states most vulnerable in their commitment to protecting their own citizens. In sum, self-interest, when combined with its universalization into an abstract principle, dictates an obligation to refugees. Adelman, supra note 22, at 84.

26. The Dublin, Schengen, and U.S.-Canada agreements, see supra note 8, are burden-sharing mechanisms, but they seek to restrict protection, not expand it. The three primary examples of large-scale burden-sharing-the CPA in southeast Asia, the International Conference on Assistance to Refugees in Africa, and the International Conference on Central American Refugees-are discussed in Hathaway \& Neve, supra note 22.

27. See generally INDEPENDENT COMM'N ON INT'L HUMANITARIAN ISSUES, REFUGEES: THE DYNAMICS OF DISPLACEMENT (1986). Some smaller, regional resettlement programs based on burdensharing principles have also been somewhat successful. 
principal desiderata. ${ }^{28}$

After the sweep of communist victories in southeast Asia in 1975, well over two million people fled Vietnam, Cambodia, and Laos for "first asylum" in neighboring countries. ${ }^{29}$ Before 1979 , these people received relatively little international assistance, and refugee camps were poorly organized. ${ }^{30} \mathrm{~A}$ coordinated international response began in July 1979, when the United Nations convened an international conference in Geneva to seek solutions to the burgeoning refugee crisis. Conference participants were attentive to the differing abilities of countries to assist the refugees. In its report on the conference, UNHCR noted that "[s]ince the countries of first asylum were developing countries confronted with serious economic and social constraints, it was essential that countries outside the area assumed the principal responsibility for resettlement."31

The sixty-five governments attending the Geneva conference agreed to three principal commitments: ${ }^{32}(1)$ countries in the region would provide at least temporary asylum; ${ }^{33}(2)$ the international community would offer resettlement places for those who had already fled; $;^{34}$ and (3) the countries of origin would discourage hazardous departures and would cooperate with the United Nations and other countries to promote direct outflows through an Orderly Departure Program (ODP).

The 1979 accord reflected the national self-interest of the conference participants. ${ }^{35}$ Resettlement countries wanted to preserve the precarious temporary refuge policies of first-asylum countries, which were not signatories to the 1951 Refugee Convention or to its 1967 Protocol. The United States in particular was committed to protecting its wartime allies, ${ }^{36}$ and to providing "a

28. For a criticism of the CPA's human rights deficiencies, see James C. Hathaway, Labelling the "Boat People": The Failure of the Human Rights Mandate of the Comprehensive Plan of Action for Indochinese Refugees, 15 HUM. RTs. Q. 686 (1993).

29. See, e.g., Draft Declaration and Comprehensive Plan of Action, June 14, 1989, reprinted in Indochinese Refugees Conference Held in Geneva, DEP'T ST. BuLl., Oct. 1989, at 69, 71 [hereinafter CPA]; Fact Sheet: Association of Southeast Asian Nations (ASEAN), 3 DEP'T ST. DISPATCH 601, 602 (1992).

30. See Astri Suhrke, Indochinese Refugees: The Law and Politics of First Asylum, in REFUGEES AND WORLD POLrTICs 136, 145 (Elizabeth G. Ferris ed., 1985). From 1975 until the 1979 conference, only 200,000 Indochinese refugees were processed for international resettlement. See UNHCR: Report of the Secretary General, U.N. GAOR, 34th Sess., Agenda Item 83, at 5, U.N. Doc. A/34/627 (1979). By May 1979, countries had committed to resettling only 125,000 worldwide. See Court Robinson, Sins of Omission: The New Vietnamese Refugee Crisis, WORLD REFUGEE SURVEY: 1988 IN REVIEW (1989), at 5, 6. At the time of the 1979 conference, 350,000 Indochinese remained in refugee camps in the region. See UNHCR: Report of the Secretary General, supra, at 5.

31. UNHCR: Report of the Secretary General, supra note 30, at 5.

32. See Robinson, supra note 30, at 6.

33. See, e.g., Foreign Relations Authorization Act, Pub. L. No. 100-204, § 904, 101 Stat. 1331, 1402-03 (1987). First-asylum countries consisted primarily of members of the Association of Southeast Asian Nations (ASEAN)-including Indonesia, Malaysia, the Republic of the Philippines, Singapore, and Thailand-as well as Hong Kong.

34. The principal resettlement countries included the United States, Canada, Australia, and France.

35. Mutual self-interest among Central American countries moving toward peace also accounted for the success of the 1989 Conference on Central American Refugees. See Hathaway \& Neve, supra note 22.

36. See, e.g., Bill McCollum, Land Vietnamese in Thailand-An Inadequate Response, WorLD REFUGEe SURVEY: 1985 IN REVIEW (1986), at 19, 20; see also The Refugee Act of 1980 and Its 
noncommunist alternative to the peoples of Indochina." ${ }^{37}$ In addition to providing humanitarian assistance, the U.S. interest was served by a system that accorded presumptive refugee status to all those fleeing the southeast Asian communist regimes. ${ }^{38}$ The resettlement program also supported the conventional immigration policy goals of resettlement countries. ${ }^{39}$

First-asylum countries in southeast Asia, burdened by the expense and political difficulties of providing refuge, hoped to stem the tide of refugees and spread the costs of assistance. As one observer noted, these countries were persuaded to provide first asylum by the "assurance that the international community will effectively take care of the refugees, and the smooth operation of a resettlement programme aiming at an equitable sharing of the burden imposed on the southeast Asian countries. " 40 The cooperation of the firstasylum countries was also bolstered by Vietnam's agreement to reduce the outflows by resuming its dubious policy of prohibiting illegal departures ${ }^{41}$ and by creating an in-country Orderly Departure Program (ODP). Finally, the costs to first-asylum countries were reduced by agreements to place some firstasylum camps under UNHCR auspices and to have UNHCR cover the direct costs of their operation..$^{42}$

The Geneva conference produced immediate results. In 1979, thirty-eight countries accepted Indochinese refugees for resettlement. ${ }^{43}$ Vietnam clamped down on smuggling operations, causing an immediate decline in refugee outflows. ${ }^{44}$ Resettlement rates increased, causing the population of boat people in the region to decline from 205,000 in mid-1979 to 40,000 three years later. ${ }^{45}$ From 1979 until 1989, over 1.7 million Indochinese refugees were resettled

Implementation, Statement Before the House Judiciary Comm. (Apr. 30, 1980), in 19 I.L.M. 700 (statement of Ambassador Victor H. Palmieri) [hereinafter Palmieri].

37. Suhrke, supra note 30, at 145; cf. Hathaway \& Neve, supra note 22 (noting U.S. desire to punish and isolate Vietnam).

38. See, e.g., Suhrke, supra note 30, at 136-37; see also Court Robinson, Buying Time: Refugee Repatriation from Thailand, WORLD REFUGEE SURVEY: 1992 IN REVIEW (1993), at 18.

39. The ODP, for instance, served those with family members in the United States and other Western countries. See Kenneth J. Conboy, An American Agenda for the Geneva Conference on Indochinese Refugees, Heritage Foundation Reports, No. 104, June 2, 1989, available in LEXIS, News Library, Arcnws File.

40. Atle Grahl-Madsen, Protection of Indochinese Refugees, in ROUND TABLE ON HUMANITARIAN ASSISTANCE TO INDO-CHINA REFUGEES AND DisPLACED PERSONS 69, 70 (International Inst. of Humanitarian Law ed., 1980).

41. See Suhrke, supra note 30, at 139.

42. See id. at 145. UNHCR's expenses were covered mainly by donations from Japan and the United States. See id. The costs of running the camps were significant. For instance, in 1979 Hong Kong spent \$14 million to establish and run camps. See Roda Mushkat, Hong Kong: Refugees and Displaced Persons-The Hong Kong Experience, in ROUND TABLE OF ASIAN EXPERTS ON CURRENT PROBLEMS IN THE InTERnAtional PROTECTION OF ReFugees AND Displaced PERSONS 96, 97 (International Inst. of Humanitarian Law ed., 1980).

43. See Ingrid Waller, Social Assistance and Integration Programs in the USA, in RouND TABLB on HumantTarian Assistance to Indo-China Refugees and DisplaCed PERsons, supra note 40, at 20, 20. By March 1979, France had accepted over 62,000 refugees, Canada over 47,000, and Australia over 37,000 . See id. By the end of that year, 290,000 refugees had been resettled in the United States alone. See id.

44. See Robinson, supra note 30, at 6; see also Suhrke, supra note 30, at 139.

45. See Robinson, supra note 30 , at 7. 
under the framework laid out at the 1979 conference, ${ }^{46}$ and over 150,000 left through the ODP. 47

In addition to the confluence of national self-interests, the Indochinese resettlement program demonstrates three points about burden-sharing. First, full-scale international cooperation was implemented under the leadership of the United States and UNHCR. UNHCR coordinated international discussions, established refugee camps and holding centers, channeled funds to care for the refugees, and monitored the implementation of the resettlement programs. The United States, the largest resettlement country, shouldered a significant share of the costs. ${ }^{48}$ The sheer number of cooperating countries reflected, at least in part, U.S. leadership. ${ }^{49} \mathrm{Had}$ the United States and UNHCR not borne the brunt of the resettlement and organizational burdens, the international consensus might have unraveled.

Second, the program's success depended upon the full cooperation of all countries involved; any shirking of one country's responsibilities could upset the precarious international balance. Several incidents illustrate this point. In May 1989, Malaysia instituted a policy of turning back boatloads of Vietnamese refugees and migrants, ${ }^{50}$ likely causing some neighboring countries to experience a drastic increase in boat arrivals. In Indonesia, for instance, 3787 Vietnamese arrived in May alone-the highest figure since the beginning of the outflow. ${ }^{51}$ Another such example occurred in 1986, when Vietnam suspended

46. See id. at 6. More than half of the refugees were resettled in the United States. By 1991, the United States had resettled 1,127,401 Indochinese refugees-745,576 of whom were Vietnamese. See U.S. Has More Than 1.1 Million Refugees from Indochina, AGENCE FRANCE PRESSE, Dec. 19, 1991, at 2. The rest of the refugees were divided among other resettlement countries. In addition, 280,000 Vietmamese who fled to China were permanently resettled there. See East Asia and the Pacific, WORLD REFUGEe SURVEY: 1989 IN REVIEW (1990), at 51, 53.

47. See East Asia and the Pacific, WoRLd RefugeE SURVEY: 1988 IN REvIEW (1989), at 49, 55; Robinson, supra note 30 , at 8.

48. From 1979 to 1989 , the United States contributed over half a billion dollars to the care and support of Indochinese refugees. See Lawrence S. Eagleburger, Statement at the International Conference on Indochinese Refugees (June 18, 1989), reprinted in DEP'T ST. BULL., Oct. 1989, at 69, 70. In addition, the United States spent several billion dollars in resettlement costs. According to a 1989 State Department estimate, the United States spends $\$ 7000$ for each refugee resettled- $\$ 2000$ for transportation and resettlement and $\$ 5000$ for social services. See Robert Pear, U.S. Raises Quota of Soviet Refugees by Cutting Asians', N.Y. TMmE, Jan. 12, 1989, at A1. Considering that the United States resettled over 1.1 million refugees, its financial contribution to the resettlement effort was significant. Japan also contributed significant financial resources to the resettlement effort. See 11 Billion Yen Aid To Be Offered to Indochina Refugees, JAPAN ECON. NEWSWRE, July 6, 1985, available in LEXIS, News Library, Arcnws File (reporting Japan's pledge to cover half of cost of UNHCR general relief programs for Indochinese refugees and to donate additional 11 billion yen to these refugees). Japan, however, did not accept many refugees for resettlement. From 1979 until 1991, less than 8000 refugees were resettled in Japan. See East Asia and the Pacific, World ReFugeE SURVEY: 1991 IN REVIEW (1992), at 56, 61.

49. In a 1980 speech, the U.S. Coordinator for Refugee Affairs stated:

President Carter's pledge to double our rate of resettlement of Indochinese refugees to 14,000 a month was a critical factor in generating new resettlement pledges by over 20 countries at the Geneva conference last July. Support from the international community encouraged Southeast Asian countries to begin once again to grant asylum to all new arrivals.

Palmieri, supra note 36 , at 700 .

50. See East Asia and the Pacific, World Refugee SuRVEY: 1990 In Review (1991), at 60, 64.

51. See id. at 62 . 
interviews of ODP applicants for U.S. departures. ${ }^{52}$ As a result, illegal departures from Vietnam surged, along with the number of arrivals in firstasylum countries. The neighboring countries responded by refusing asylum to the new arrivals. Thailand, for example, began sending back boats and denied those migrants who were admitted an opportunity to seek resettlement. Similar reactions occurred in Indonesia and Hong Kong. ${ }^{53}$ In sum, one country's defection triggered exclusionary reactions in others; ${ }^{54}$ interlocking interests contributed not only to the implementation of burden-sharing programs, but also to their effective maintenance.

Third, effective burden-sharing requires efforts to reduce the burdens on all countries and spread them over time. As the Indochinese resettlement program progressed, countries began worrying that it caused a "pull effect" by encouraging people to flee their countries in search of resettlement in the West. ${ }^{55}$ As the number of boat arrivals increased and the average stay in the refugee camps lengthened in the late 1980 s, first-asylum countries began taking unilateral and sometimes inhumane measures to deter further arrivals and to reduce camp populations.

In response to these concerns, the resettlement program was refined in 1989 at a second Geneva conference on Indochinese refugees. The conference participants adopted a new program, the Comprehensive Plan of Action (CPA), to address the Vietnamese and Lao refugee problems. ${ }^{56}$ The CPA, which was scheduled to expire on June 30,1996, preserved the basic framework of the earlier resettlement program, with one modification. Under the CPA, refugee status was no longer conferred automatically on all those who arrived in firstasylum countries; instead, arrivals were subject to refugee screening by local immigration officials. Those screened in were eligible to seek resettlement in a third country, while those screened out remained in holding centers and faced

52. See Robinson, supra note 30 , at 6 . Vietnam did so to protest a backlog of 22,000 cases. See id.

53. See id.; see also Phan Quang Tue, Going Back Against the Tide, RECORDER, Dec. 19, 1991, at 6.

54. This holds true in other refugee contexts as well. As one commentator has aptly noted, "[u]nilateral deterrence pushes the problem onto a neighbour." Barry N. Stein, The Nature of the Refugee Problem, in HUMAN RIGHTS AND THE PROTECTION OF REFUGEES UNDER INTERNATIONAL LAW, supra note 15 , at 47,65 . As an example, Stein cites a one-year jump in Norway's asylum caseload from 300 to 8000 applicants after neighboring countries closed their borders. Id. (citing Jeff Crisp, Nonvay: Asylum Policy: The Humanitarian Dilemma, REFuGEES, Aug. 1987, at 13, 14); see also Dennis Gallagher et al., Temporary Safe-Haven: The Need for North American-European Responses, in REFugEES AND INTERNATIONAL RELATTONS 333, 335-36 (Gil Loescher \& Laila Monahan eds., 1989) (discussing interconnectedness of asylum policies and examples). This point also applies to the actions of resettlement countries. For instance, when the United States was sluggish in fulfilling its ODP resettlement commitments, Vietnam retaliated by halting the program. See supra note $\mathbf{5 2}$ and accompanying text. Similarly, when the United States reduced its ODP ceiling in 1989 to accommodate refugees from the former Soviet Union, Vietnam responded by suspending discussions on allowing 50,000 former political prisoners and their families to emigrate. See Robinson, supra note 30 , at 10.

55. See, e.g., Robinson, supra note 30, at 7-8; Suhrke, supra note 30, at 148. According to Robinson, the "reasons for flight [were] compelling and varied, but it is fair to say that virtually all have left, not in search of asylum, but in search of resettlement." Robinson, supra note 30, at 8 (citing study by Ford Foundation).

56. The CPA dealt only with Vietnamese and Lao refugees. Negotiations regarding Cambodian refugees (who were included in earlier resettlement programs) were conducted separately. 
eventual repatriation. ${ }^{57}$ To balance concerns over national sovereignty and human rights, conference participants agreed to establish a "region-wide refugee status-determination process . . . in accordance with national legislation and internationally accepted practice," including UNHCR training and oversight. ${ }^{58}$ To secure the support of first-asylum countries, resettlement countries committed to expedited resettlement of all refugees who arrived prior to the cut-off date set by the CPA. ${ }^{59}$ The CPA also called for additional countries to join the resettlement effort. ${ }^{60}$

At the time of the sixth follow-up meeting of the Steering Committee of the International Conference on Indochinese Refugees in March 1995, there remained 36,339 screened-out Vietnamese and 2048 with refugee status in firstasylum countries. ${ }^{61}$ Although the Steering Committee called for the completion of all repatriation and resettlement by the end of 1995, the process was delayed both because a number of screened-out Vietnamese refused to be repatriated at all costs, and because the United States proposed to offer screened-out boat people a second chance to apply for refugee status according to U.S., not CPA, refugee criteria. ${ }^{62}$ Word of the U.S. proposal caused "violent anti-repatriation protests" in the camps and impeded the repatriation and resettlement under the CPA. ${ }^{63}$ In early 1996 , the Vietnamese government and the United States agreed to procedures whereby "[p]otential returnees would register for a U.S. interview before departing the camps. Upon return to Vietnam, they would go back to their areas of origin to await their interview. Those accepted would be processed for U.S. resettlement." ${ }^{.64}$ UNHCR announced that the CPA would formally end on June 30, 1996.

\section{FOUR REMEDIAL STRATEGIES}

Broadly speaking, the problem of massive refugee flows can be addressed in only four ways. ${ }^{65}$ I shall call these the root cause, repatriation, temporary

57. See CPA, supra note 29, para. E(9)(b). See generally Robinson, supra note 38; Hiram A. Ruiz, The CPA: Tempestuous Year Left Boat People Adrift, WORLD REFUGEE SURVEY: 1995 IN REVEW (1996), at 82 .

58. CPA, supra note 29, para. D(6).

59. See id. para. $\mathrm{E}(9)$ (containing multi-year commitment to resettle all Vietnamese who arrived in temporary asylum camps prior to agreed date). The United States, for instance, agreed to resettle 22,000 of the 52,000 long-stayers. See Eagleburger, supra note 48, at 70. Australia committed to resettling 11,000 Iong-stayers. See East Asia and the Pacific, supra note 46, at 51.

60. CPA, supra note 29, para. E(9)(a). Specifically, the CPA named the following countries as resettlement candidates: Australia, Austria, Belgium, Canada, Denmark, Federal Republic of Germany, Finland, France, Ireland, Italy, Japan, Luxembourg, the Netherlands, New Zealand, Norway, Spain, Sweden, Switzerland, United Kingdom, and the United States. Id.

61. See Ruiz, supra note 57, at 82 . From the beginning of the CPA in 1989 until the 1995 meeting, approximately 80,000 Vietnamese were resettled in the West, and over 72,000 others were repatriated to Vietnam. See id.

62. See id.

63. Id. at $82-83$.

64. Id. at 83 .

65. I exclude the strategy of altering the legal definition of "refugee." Because narrowing the definition would deny protection to some individuals who deserve and desperately need it, virtually all 
protection, and permanent resettlement strategies. Each has its own distinctive advantages and disadvantages. In Part V of this Article, I describe, and in Part VI defend, a novel version of the temporary protection and permanent resettlement strategies, which I call proportional burden-sharing.

It is essential to emphasize at the outset (and I shall repeat this point later on) that although I focus on temporary protection and resettlement through proportional burden-sharing, I wish to emphasize that they are the least attractive of the four strategies in principle, and sometimes even in practice. In short, they are-particularly resettlement-strategies of last resort, but all too often they are the only resorts. The grim reality is that the root cause and repatriation strategies are often either unavailable or implemented in ways that fail to protect refugees as well as even an imperfect system of proportional burden-sharing might.

One may argue that this need for large-scale temporary protection and resettlement was historically contingent, a function of the political and military patterns associated with the Cold War. According to this view, the end of the Cold War meant the cessation of long, remorseless wars of national liberation fueled by Soviet-sponsored regimes implacably hostile to returning refugees. With the spread of democratic governance (so the argument runs), the refugee flows of today and tomorrow are more environmentally than politically or ideologically driven; hence refugees can readily return once the environmental crisis is over. ${ }^{66}$

This cheerier scenario may come to pass, but there is as yet little evidence to support this optimism and, in fact, some that tends to contradict it. The most recent empirical study suggests that although the sources of refugee flows are indeed changing, the violence and the distribution of weaponry per conflict are increasing, making refugee repatriation more difficult. ${ }^{67}$ As for the future, there are ominous signs of possible refugee flows from Hong Kong now that it is under the control of the People's Republic of China.

Nevertheless, my argument in favor of a burden-sharing system does not rest on any strong claim about the particular level of protection that future crises may require. To support my argument, it is enough that significant protection is likely to become a compelling need sometime within the political time horizon of the major receiving states; that the uncertainties about the

proposals for change urge that the definition be broadened. See, e.g., Frederick B. Baer, International Refugees as Political Weapons, 37 HARV. INT'L L.J. 243 (1996); Isabelle R. Gunning, Expanding the Intemational Definition of Refugee: A Multicultural View, 13 FORDHAM INT'L L.J. 35, 72-85 (1990). Whatever the merits of broadening the refugee definition, however, such a reform would simply multiply the problems discussed in the text. See supra note 19 (discussing broader refugee definitions).

66. For example, Professor Peter J. Spiro, writes:

Of course there are still some pretty nasty regimes scattered here and there, but without the backbone that communism provided, they are likely, at least in most cases, not to last forever, so that temporary protection should suffice for those fleeing such conditions. I think it's unlikely that we will witmess anything like the Vietnamese refugee crisis anytime soon.

Letter from Peter J. Spiro, Professor, Hofstra University, to the author 1 (July 1, 1996) (on file with author).

67. See Weiner, supra note 3. 
timing, magnitude, duration, and resolution of the precipitating refugee crises are seriously problematic for these states (not to mention for the refugees); and that these states view as unsatisfactory the ad hoc improvisations that have been used to handle this problem in the past.

My argument for a formal system of proportional burden-sharing, then, is a decidedly qualified one. It proposes that in situations in which the root causes of a refugee crisis can be prevented or eliminated, or in which repatriation can be safely accomplished, those strategies are preferable to proportional burdensharing and should be pursued. ${ }^{68}$ Only in situations in which these conditions cannot be satisfied does a system of proportional burden-sharing, implemented through either temporary protection or, in the last resort, permanent resettlement, become salient.

\section{A. The Root Cause Strategy}

Eliminating or preventing the political, economic, environmental, and cultural conditions that prompt refugees to flee their homes and countries in the first place is the most attractive approach by far. Obviously, this strategy, if effective, precludes the necessity for flight and hence forestalls the suffering that attends it.

The difficulty with a root cause strategy, of course, is that it is extremely difficult to execute. ${ }^{69}$ One must be able to identify accurately the conditions ultimately prompting flight and then be able to rectify those conditions. Both identification and rectification are daunting obstacles.

The easiest case for identifying root causes should be the environmental disaster. Yet even here, causal patterns are often complex and elusive, as when environmental conditions interact with underlying economic and social practices to produce a catastrophe that would not have occurred otherwise.$^{70}$ As for persecution-induced flight, even a readily identified malefactor or regime, such as Castro's Cuba or Hussein's Iraq, may not be the root cause. As in the environmental case, the brutal regime's hegemony could be epiphenomenal, with the true causes embedded in underlying political or cultural traditions-habituation to authoritarianism, for example-that would probably survive the regime. ${ }^{71}$

68. Participants in a research consortium based at York University's Centre for Refugee Studies are elaborating a strategy for refugee law reform based on a commitment to rights-regarding temporary protection and dignified repatriation. See generally James C. Hathaway, Can International Refugee Law Be Made Relevant Again?, WORLD REFugEE SURVEY: 1995 IN REVIEW (1996), at 14.

69. See James C. Hathaway, Root Causes as Refugee Protection: A Chimerical Promise?, in IMMIGRATION AND EUROPEAN UNION: BUILDING ON A COMPREHENSIVE APPROACH 117, 117-21 (S. Perrakis ed., 1995).

70. Examples include famines, which are sometimes caused or at least exacerbated by inefficient agricultural policies and distribution systems, and floods, which sometimes reflect perverse patterns of tidal land development.

71. Even in relatively democratic societies, such traditions appear to play an important role in differentiating political and economic outcomes. See ROBERT D. PUTNAM, MAKING DEMOCRACY WORK: CIVIC TRADITIONS IN MODERN ITALY 183-85 (1993) (noting that social capital is dominant factor). 
An even more serious obstacle to a successful root cause strategy, however, is the problem of rectification. Even those root causes that can be accurately identified are often impossible to change-at least in the short run and with the limited policy instruments available even to states willing (within limits) to act to prevent human rights abuses. The fecklessness of the United Nations in dealing with refugee-producing atrocities committed by local satrapies in the former Yugoslavia is a particularly telling and grim example. In part, this impotence reflects the constraints on intervention posed by the strong norm of national sovereignty in international law and politics. ${ }^{72}$ Despite several recent instances in which this norm has been overridden in the name of human rights, ${ }^{73}$ that norm continues to be a formidable limitation on our ability to mount and deploy a root cause strategy in other states. Even if the norm against intervention did not exist, the underlying social realities are notoriously hard to reform-even in one's own country, not to mention in other societies whose workings we understand far less. In such circumstances, the law of unintended consequences operates with a particularly remorseless logic.

Not surprisingly, the most common and uncontroversial means through which states seek to prevent the flow of refugees and other migrants from source countries are the consensual policies of trade, investment, development assistance, and other forms of foreign aid. Along with border controls, such policies-culminating in NAFTA-have been the cornerstone of U.S. efforts to reduce the flow of undocumented workers and their families from Mexico. ${ }^{74}$ But while these policies may be mutually beneficial and highly desirable on their own terms, their potential for strengthening the source country's economy, polity, and society in ways that will reduce refugee and immigrant flows-at least in the short run-is relatively limited. ${ }^{75}$

72. It is not simply physical invasions of a state's territory that the norm of state sovereignty constrains. The norm also prevents a state that has borne the costs of another state's refugee-generating policies or practices from suing the source state to recover those costs. Establishing such a cause of action could-assuming that the source state's causal responsibility could be proved and the resulting judgment could be enforced-render a root cause strategy far more effective. The freezing of Iraq's assets abroad and the embargo on its crude-oil sales after the Persian Gulf War were modest steps in that direction. By way of analogy, consider other intergovernmental transfer obligations: the U.S. government's obligation under the 1995 unfunded mandate legislation to reimburse state and local govemments for their costs of complying with certain federally-imposed requirements, see Unfunded Mandates Reform Act of 1995, Pub. L. No. 104 4, 109 Stat. 48, and the Elizabethan poor laws' provision for communities receiving destitute residents of other communities to charge the latter for certain maintenance costs, even to the point of litigatio, see, e.g., MiChaEl KATZ, THE UNDESERVING POOR 11-12 (1989). But see International Law Ass'n, Draft Declaration of Principles of International Law on Compensation to Refugees and Countries of Asylum (Report of the 64th Conf., 1991), reprinted in 64 INT'L L. PROC. 333 (1991).

73. These instances include the creation after the Persian Gulf War of a "safe zone" in northern Iraq to protect the Kurdish minority there, and the U.S. invasion of Haiti to restore President Aristide. Another example is the ill-fated ECOMOG involvement in Liberia. See, e.g., Hugh Dellios, No More Rwandas? U.S. Proposal for All-African Peacekeeping Force Draws Fire, CHI. Trib., Oct. 8, 1996, at 3 (noting corruption and partisanship of ECOMOG troops).

74. See, e.g., James F. Smith, NAFTA and Human Rights: A Necessary Linkage, 27 U.C. Davis L. REv. 793, 800-01 n.22, 841 n.202 (1994).

75. See Christopher Mitchell, The Impact of U.S. Policy on Migration from Mexico and the Caribbean, in MigRanTs, RefugeEs, AND Foreign POLICY: U.S. AND GERMAN POLICIES TOWARD COUNTRIES OF ORIGIN, supra note 3. 
Indeed, economic development in the source country may actually have the opposite effect. By increasing the education and mobility levels of potential migrants, improving their information about conditions and opportunities in destination countries, and raising their expectations, economic development can encourage those with the greatest energy, courage, and determination to try their luck elsewhere. Development also tends to create a middle class that demands political liberalization from undemocratic regimes, which may respond with the kinds of repressive measures that often generate refugee flows. ${ }^{76}$ Again, the capacity of economic and political development to ameliorate human rights abuses and stem refugee and immigrant flows cannot seriously be questioned. However, the course and pace of such development and its effects on migration patterns are poorly understood and notoriousily unpredictable. Root cause strategies that are premised on the easy cultivation and rapid success of development are likely to be disappointing.

\section{B. The Repatriation Strategy}

If, as is usually the case, the root causes of refugee flows cannot be prevented or eliminated, it follows that refugees will flee. In that event, the paramount goal of a human-rights strategy must be to restore the normalcy of refugees' lives by returning them to their homes and families as soon as possible. This approach is more practicable than the root cause strategy and is likely to be far less expensive, as it does not require (indeed, it hopes to prevent) refugees from establishing new roots in the country of refuge.

In fact, many refugees are eventually repatriated ${ }^{n}$ some within a relatively short period of time after their initial flight. For the others, however, "eventually" can be a very long time indeed. ${ }^{78}$ In principle, repatriation should not occur until conditions in the source country have stabilized enough for the refugees to return safely. If the regime that persecuted them remains in power, such a return may be dangerous. Their homes and businesses may have been seized, occupied, or formally expropriated by the regime or private marauders, leaving them little to which they can return. They also may have reason to fear death or other reprisals at home should they return. For these reasons, voluntary repatriation may not be possible for years, even for those refugees who ardently wish to return to their homelands, while forcible repatriation may

76. See NAFTA, Non-Trade Related Issues: Immigration, MEX. TRADE \& L. REP., Nov. 1993, at 9, 11 (noting that economic development may, in short term, increase migration).

77. For some statistics on voluntary and involuntary repatriations, see World Refugee Statistics, supra note 2 , at 7 tbls.5, 6 .

78. See, e.g., John Kifner, Conflict in the Balkans: A Holocaust Rescuer Is Herself Rescued from Siege of Sarajevo, N.Y. TIMES, Feb. 8, 1994, at A15 ("Many [members of Sarajevo's Jewish community] arrived here carrying the keys to their homes in Spain in the belief that they would soon return there, and many of the keys have been handed down through many generations."); Sebastiao Salgado, War Without End, N.Y. TIMES MAG., July 30, 1995, at 24 (reporting that 40,000 Vietnamese boat people remain in detention camps after 20 years). For the Palestinian refugees who lived in and wish to return to what is now Israel, repatriation is not in sight after almost half a century. This is admittedly an unusual case. 
be resisted even to the point of violence or suicide. ${ }^{79}$

The "end-game" of the CPA, which was scheduled to expire on June 30 , 1996 , presented a variation on the same theme. With more than one million Indochinese refugees resettled since 1975, mostly in the United States, approximately 33,000 boat people, whose claims to refugee status had been repeatedly rejected, remained in southeast Asian camps. Under the CPA, these people were to be repatriated-by force, if necessary. In the United States, Senator Jesse Helms, Congressman Christopher Smith, and other elected officials opposed repatriation, insisting that these refugees would face persecution if returned to Vietnam and that they should instead be permitted to resettle in the United States. This, in turn, emboldened the remaining boat people to resist repatriation to the point of violent rioting, destroying camp buildings, taking hostages, and in many cases escaping. The United States, unwilling to face the prospect of effectuating a forcible repatriation that might require it to spill the blood of innocents who had already suffered for years in the camps, reached an eleventh-hour agreement with Vietnam for a repatriation that for many of the returnees may only be brief. Under the agreement, they will be returned to Vietnam where they will be permitted to file yet another claim for refugee status and apply once again for resettlement in the United States. It was expected that thousands of these claims would succeed. ${ }^{80}$ In this way, the United States has adopted a new sub-strategy-what might be called "temporary repatriation."

\section{The Temporary Protection Strategy}

If conditions in the source country make immediate repatriation (whether temporary or permanent) impossible, one must adopt an interim approach until the refugees can be safely returned. This, of course, is the purpose of granting political asylum; it is a temporary protected status that may, but need not, lead to a right of permanent residence. Indeed, if the conditions in the source country change so that the threat of persecution no longer exists, asylum may be properly rescinded. ${ }^{81}$

But although traditional refugee law is preoccupied with questions of asylum eligibility, determination, and rights, the number of individuals granted asylum is but a tiny fraction of those who actually receive protection and an

79. See, e.g., Gargan, supra note 20 (reporting that refugees in Hong Kong rioted when faced with repatriation to Vietnam); James C. McKinley, Jr., Some Rwandan Exiles Can't Go Home Again, N.Y. TIMES, Feb. 7, 1996, at A8 (reporting that because of fear of reprisals, Hutu refugees refuse to return despite harsh conditions in camps and campaign by UNHCR to convince them of safe conditions at home); Seth Mydans, In Thai Camps, Fear of Burmese Troops Grows, N.Y. TmES, Mar. 3, 1997, at A3 (describing new policy of Thai government that only women, children, and elderly among Burmese refugees will be allowed to stay in Thailand).

80. See Steven Erlanger, U.S. and Hanoi Agree To Give Boat People One Last Chance, N.Y. TIMES, May 15, 1996, at A13; see also Gargan, supra note 20.

81. See 8 U.S.C. \& 1158(b) (1994). This cessation provision follows article $1(C)(5)$ of the 1951 Refugee Convention, surpa note 1. 
even smaller fraction of those who genuinely need protection. Most countries of first asylum have concluded that the fiscal and political costs of adjudicating mass asylum claims, granting employment and residence rights while those claims are pending, and permanently integrating asylees into their societies are simply unacceptable. ${ }^{82}$ As a result, asylum law has become less and less relevant to the protection problem in mass influx situations..$^{83}$ Other solutions are desperately needed.

Instead of granting asylum, the more common response of states faced with large refugee influxes-even those with highly developed asylum determination systems and absorptive capacity-has been to provide some form of temporary protection in the protecting state. ${ }^{84}$ Properly and humanely deployed, ${ }^{85}$ it can be a flexible, practicable regime of protection in mass influx situations so long as states observe certain safeguards-especially decent living standards, access to a fair asylum determination process, and genuine non-refoulement.

If these conditions are met, there should be no objection to a protecting state "renting space" outside of its territory to provide temporary safe haven. ${ }^{86}$ Indeed, temporary protection has the great virtue that it can usually be effectuated in or near the first-asylum state, which tends to be near the refugee's country of origin. It therefore minimizes the psychological and economic costs of moving the refugee again, safely maintaining her in her present location and close to her past and hopefully future home. Moreover, because grants of asylum or permanent resettlement are relatively rare, and safe repatriation may be impossible, the refugee's options are likely to be temporary protection or nothing.

82. See, e.g., GRUNDGESETZ [Constitution] [GG] art. 16(a)(4) (F.R.G.) ("The implementation of measures terminating a person's sojourn shall . . . be suspended by the court only where serious doubt exists as to the legality of the measure....").

83. See Joan Fitzpatrick, Flight from Asylum: Trends Toward Temporary "Refuge" and Local Responses to Forced Migrations, 35 VA. J. INT'L L. 13, 16 (1994).

84. It is sometimes called temporary refuge, temporary asylum, or temporary safe haven. Those who receive it are sometimes called de facto refugees. This is to be distinguished from the creation of "safe areas" for refugees in the state of origin, as the United States and its allies did in Iraq after the Persian Gulf War. For a discussion of other variants of safe haven, see Weiner, supra note 3 (distinguishing among models in which powerful third country controls safe territory elsewhere (Guantanamo), self-administered safe zones within country of origin (Kurds in Iraq), and internationally protected safe zones within country of origin (Bosnia)). As Fitzpatrick notes, temporary refuge "has become more regularized and formalized, assuming an unaccustomed prominence in the refugee policies of European states." Fitzpatrick, supra note 83, at 16; see also Joanne Thorburn, Transcending Boundaries: Temporary Protection and Burden-Sharing in Europe, 7 INT'L J. RefugeE L. 459 (1995).

85. Joan Fitzpatrick and others criticize temporary protection as simply one more transparent device (like detention, denial of work permits, and other such policies) to constrict migrants' access to the rights and remedies established for Convention refugees. See, e.g., Fitzpatrick, supra note 83, at 16-18; Harold Hongju Koh, America's Offshore Refugee Camps, 29 U. RICH. L. REv. 139 (1994) (chronicling, describing, and criticizing U.S. temporary protection policies toward Haitians and Cubans); see also Gerald L. Neuman, Recent Trends in United States Migration Control, 38 GERMAN Y.B. INT'L L. 284, 288-98 (1995) (discussing Koh article).

86. Just as the United States procured such space in the Caribbean, so European and Asian states could do so in their regions. Section 604 of IRIRA excepts from the statutory right to apply for asylum those aliens who can be removed, pursuant to a bilateral or multilateral agreement, to a third country that is "safe" (as defined by the provision). See Illegal Immigration Reform and Immigrant Responsibility Act of 1996 (IIRIRA), Pub. L. No. 104-132, § 604, 110 Stat. 1214 (amending 8 U.S.C. § 1158). 
Temporary protection is also a desirable strategy from the perspective of industrialized states' narrow self-interest. It is a way to keep refugees safely (in both senses) in the Third World from which most of them come, thereby alleviating the pressures to grant them permanent resettlement in the First World. Any refugee protection scheme that does not promise to accomplish these goals is unlikely to attract the necessary political support by industrialized states. It is for this reason that a meaningful system of refugee protection must rest on the foundation of a viable temporary refuge option.

Even so, temporary protection can impose serious costs on industrialized states. If temporary protection is to succeed in deterring migration to their territories, these states must ensure that the migrants are protected under conditions of detention, isolation, and privation with little hope of gaining legal status, while also providing levels of safety and hygiene demanded by their domestic standards of decency, if not by the vague common-denominator norms of international refugee law. This is an exceedingly difficult balance to strike, and even such minimal levels of amenity can be very costly for the government to maintain, especially over a long period of time..$^{87}$

Time, then, is of the essence. The protecting state may find that "temporary" safe haven is something of an illusion, if not an oxymoron-that what was justified as short-term relief has a way of becoming, in effect, permanent resettlement. ${ }^{88}$ This development is of the utmost importance for the future of refugee protection. If potential protecting states come to believe that refuge granted on a nominally "temporary" basis is likely to become permanent, they will be more reluctant to offer it.

87. The United States, for example, spent $\$ 1$ million per day to maintain its refugee camps on the Guantanamo Bay Naval Base. See U.S. Policy Toward Cuba: Hearings Before the W. Hemisphere Subcomm. of the Senate Foreign Relations Comm. (1995) (statement of Peter Tarnoff, Under Secretary for Political Affairs), reprinted in 6 U.S. DEP'T ST. DiSPATCH 446, 451 (1995); Gillian Gunn, Over Troubled Waters: U.S. Policy Toward Cuba Has Changed, but Does the President Know It?, WASH. POST, May 21, 1995, at C2. In 1979, Hong Kong spent $\$ 14$ million to establish and run camps. See Mushkat, supra note 42 , at 97. In the view of some knowledgeable observers, even these expenditures have not produced adequate conditions. Professor Koh, who represented the migrants on Guantanamo against the U.S. government, calls for

shelters capable of withstanding the elements; refugees housed in family groups and allowed freedom of movement within the camps; private voluntary agencies, nongovernmental organizations, and the United Nations High Commissioner on Refugees, not the United States military, running the camp's religious, education [sic], and recreational services; the United States Public Health Service and not the military providing health care; with mail and phone access made available to the refugees, along with ready access of press, human rights monitors, volunteer religious organizations, and doctors. Social activities at the camps-education, religion, books, recreation, intracamp communication and the like-must be greatly expanded to maintain morale and reduce tensions and frustration. . . . The access of lawyers and legal counseling is as important to the success of these camps as medical counseling.

Koh, supra note 85 , at 171-72.

88. Virtually all proponents of temporary protection say far more about protection than about its temporary aspect. See, e.g., Thorburn, supra note 84 . Yet it is clear that states will not provide this remedy unless they believe that the burden will indeed be short-lived. Professor James C. Hathaway is a rare academic voice who acknowledges and seeks to deal with this reality. See Manuel A. Castillo \& James C. Hathaway, Temporary Protection, in ReCONCeiving InTERnational REFugeE LAw (James C. Hathaway ed., forthcoming 1997). 
This is increasingly the case in the United States, where temporary protection either on or near American soil has recently been ratcheted upward into more or less permanent residence. The most important example of this concerns the Salvadorans who entered the United States illegally during the 1980s and who, after having successfully avoided deportation, were granted temporary protected status (TPS) ${ }^{89}$ under the special provisions of the Immigration Act of 1990. The Act authorized such relief on the understanding that the Salvadorans would return to El Salvador once conditions there stabilized..$^{90}$ During the early 1990s, the administration and Congress extended the departure dates several times and when the program finally expired in December 1994, the Immigration and Naturalization Service (INS) granted nine more months for the Salvadorans to file for asylum or seek legal status. This concession reflected the fact that the INS had massively violated Salvadorans' legal rights in processing and rejecting their asylum claims during the 1980 s. Approximately 150,000 of them reapplied.

Most experts predict that few of the almost 200,000 original TPS Salvadorans will ever have to leave. The remaining TPS Salvadorans can now have their claims reheard, although changed circumstances have made most of these claims harder to sustain than they would have been during the 1980s. This process will drag on for years due to a current and growing backlog of over 400,000 asylum cases..$^{91}$ The INS does not know what happened to the original 187,000 TPS Salvadorans, or how many remain (the estimate is 100,000 ), much less their names or locations. Most probably melted into the population, managed to secure legal status, or returned to El Salvador on their own. As many skeptics had predicted, TPS turned out in the Salvadoran case to be "a slow way of saying yes." ${ }^{92}$ It remains to be seen whether the six other countries' nationals who now enjoy TPS will similarly be able to bootstrap their presence in the United States into permanent residence. In any event, the Salvadoran experience makes it doubtful that the U.S. government will grant temporary protection as readily in the future.

Even when the United States moved its temporary protection program offshore by placing Cuban migrants on Guantanamo and in Panama, most of them ended up receiving permanent residence, despite the frequent insistence by the President and Attorney General that these Cubans would never be permitted to enter the United States. ${ }^{93}$ These Cubans managed to convert

89. See 8 U.S.C.A. § 1254a note (West Supp. 1997) (Special Temporary Protected Status for Salvadorans, originally enacted as Immigration Act of 1990, Pub. L. No. 101-649, § 303, amended by Pub. L. No. 102-65, 105 Stat. 322 (1991); Pub. L. No. 104-208, div. C, tit. III, § 308(g)(1), (g)(6)(A), 110 Stat 3009 (1996)).

90. For a summary history of Salvadoran TPS, see ThOMAS ALEXANDER ALEINIKOFF ET AL., IMMIGRATION PROCESS AND POLICY 889-96 (3d ed. 1995); id. at 100 (Supp. 1997).

91. Some 149,500 new applications were filed in fiscal year 1995, up slightly from 146,400 in fiscal year 1994. See Congress: Immigration, Welfare, Minimum Wages, MIGRATION NEWs, Aug. 1996, at 8 , <http://migration.ucdavis.edu/By-Month/MN-Vol-3-96/MN_Aug_96.hmtl/RTFT.C3>.

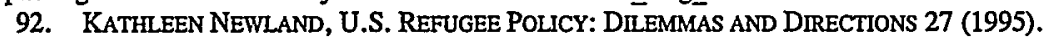

93. The same was not true of the Haitian refugees at Guantanamo. See generally Terry Coonan, America Adrift: Refoulement on the High Seas, 93 U. CIN. L. REv. 1241 (1995). 
temporary protection into permanent status not because the United States deemed them refugees-quite the contrary-but because the U.S. government, for a combination of political and fiscal reasons, was not prepared to return them to Cuba or to continue their temporary protection status in the Guantanamo and Panama camps. ${ }^{94}$

Several other forms of temporary protection have been attempted. In some cases, military action or U.N. fiat has established putatively safe enclaves in the countries of origin, as in northern Iraq and the former Yugoslavia. The conditions necessary to create and maintain such enclaves, however, are quite limited. In other cases, the destination state has negotiated bilateral or multilateral "readmission agreements" with third countries (usually countries of transit) to admit (or readmit) certain categories of migrants and to provide them with certain services and protections until they can be repatriated or their status otherwise regularized. Germany has concluded these agreements with Poland, the Czech Republic, and Romania. ${ }^{95}$ The principal purpose of such agreements, of course, is not humanitarian but more effective border control by enlisting the cooperation of neighboring states through which the migrants pass. ${ }^{96}$ From the perspective of the destination state, however, this assistance by the transit states may be costly to procure. Such arrangements, moreover, also risk human rights violations by the transit states, whose citizens are likely to be hostile to the migrants' presence. This hostility can be expected to increase as time goes on.

Temporary refuge is the keystone of the refugee protection structure. If past is prologue, states will always confine their grants of asylum and permanent resettlement to a relatively small number of refugees; for most refugees, the best that they can hope for is temporary protection. Unless the system can credibly assure states that the temporary protection they grant will indeed be temporary, its availability to refugees is likely to be undermined, with tragic effects. Thus an important test of the value of any reform is whether it can maintain that credibility. I hope to demonstrate in Part $V$ that proportional burden-sharing, through marketable quotas, would create the incentives to satisfy that test.

\section{Permanent Resettlement}

As I noted earlier, resettlement must be the protective strategy of last resort, employed only when the root causes of flight cannot be prevented or eliminated, and safe repatriation to the country of origin or to another site of temporary protection within a reasonable period of time cannot be effected. Resettlement in a third country is costly to the refugee, who must be uprooted

94. See Neuman, supra note 85 , at 293-97.

95. See Olaf F. Reerman, Readmission Agreements, in IMMIGRATION ADMISSIONS: THE SEARCH FOR WORKABLE POLICIES IN GERMANY AND THE UNITED STATES (K. Hailbronner et al. eds., forthcoming 1997).

96. See Alan Cowell, German Court Upholds Laws To Limit Foreigners Seeking Refuge, N.Y. TIMES, May 15, 1996, at A5 (noting that Constitutional Court upheld third-country transit rules). 
once again and then reestablished in a society that is likely to be alien in culture, language, and other respects. It is also costly to the receiving country, which must either assist the refugee to assimilate successfully or run the social risks of her failure to do so. These costs are likely to be much higher than temporary protection, which can lead to repatriation in the not too distant future.

As we have just seen, however, repatriation in the short term is impossible in a tragically large number of cases. This is especially true when the migration flow has been fueled by policies of uncompromising and perhaps permanent ethnic or religious persecution carried out by the regime in power in the country of origin. For persecuted minorities who have fled, the alternative to resettlement is to languish for many years in what amounts to a prison, isolated from normal social intercourse and economic activity and without the amenities of family life. In such cases, resettlement-problematic as it is-may be the "least bad" remedy.

No one knows for sure how many of the world's refugees need resettlement. Uncertainty on this question, of course, largely reflects the ambiguity of "need" in this context, the contested factual and value judgments that give content to that term, and the political considerations that affect all estimates in this area. ${ }^{97}$

Only a few countries, however, now offer permanent resettlement to a significant number of refugees. The United States accepts by far the largest number of any country, at least in absolute terms. ${ }^{98}$ In 1995 it adjusted the status of 106,827 refugees to that of legal permanent resident. ${ }^{99}$ If asylee adjustments are included, the total rises to more than 114,664 in $1995 .{ }^{100}$ Sweden, which accepts more refugees and asylees in proportion to its population than any other country, did so for about 36,400 people in 1993; Canada, with a population almost four times Sweden's, gave relief to only half as many $(18,400)$, while Australia, with twice Sweden's population, accepted fewer than one-fourth as many (8800). The Netherlands and the United Kingdom each accepted about 10,000, while Germany accepted 16,000. In both the United States and Europe, there are signs that political changes may soon reduce the number of such offers. ${ }^{101}$ Nor are other resettlement countries immune from many of the political pressures that may limit future refugee and

97. See World Refugee Statistics, WorLd REFugEe SURVEY: 1994 IN REVIEW (1995), at 42, 43 tbls.1, 2.

98. As a percentage of refugee and asylum admissions to total population, however, the United States ranked fifth behind Sweden, Canada, Australia, and Denmark in 1994. See id. at 46 tbl.9.

99. See U.S. Dep'T OF Justice, ImMigratton and Naturalization Serv., 1995 Statistical YEARBOOK OF THE IMMIGRATION AND NATURALIZATION SERVICE 83 tbl.26 (1997).

100. See id. at 91 tbl.32.

101. In what could be an augury of restrictions to come, Congress's blue-ribbon Commission on Immigration Reform recommended in June 1995 that the annual refugee quota, which was 112,000 in 1995, be reduced to 50,000. See U.S. COMM'N ON IMMIGRATION REFORM, LEGAL IMMIGRATION: SETTING PRIORITIES 131 (1995). The Commission believed that this change would still accommodate at least twice as many Convention refugees as under the current quota, which resettles many who are now accepted under a lower standard but who would not qualify as Convention refugees. See id. 
asylum admissions in the United States. ${ }^{102}$

The vast majority of countries, however, make few or no resettlement offers even though some of them have ample resources for doing so. Japan, which enjoys the second largest economy in the world, provides a particularly striking example of resistance. Japan subscribed to the Refugee Convention in 1981 and enacted implementing legislation the next year. Nevertheless, in the thirteen years between 1982 and May 1995, Japan granted asylum to only 208 refugees-an average of sixteen per year. It also resettled 8679 Indochinese refugees. ${ }^{103}$ Finally, Japan extends "special permission to stay" to a small number (393 in 1991, for example) of deportable Chinese and other Asians, a group considered "de facto refugees." 104 Japan does score higher in terms of financial and material assistance to international refugee-aid agencies ${ }^{105}$-a point to which I shall return.

This extreme concentration of resettlement offers in a few countries means that when refugee emergencies occur (as they increasingly do), UNHCR and voluntary refugee organizations move reflexively (like Claude Rains' order in Casablanca) to "round up the usual suspects." Such a response is perfectly understandable and rational; after all (as Willie Sutton noted in explaining why he robbed banks), "that's where the money is." This approach, however, is becoming more inadequate and futile in a world of seemingly endless refugee emergencies in which prompt, safe repatriation is often impossible, and temporary protection is shunned by countries fearing, with some reason, that it could become permanent and thus attract even more migrants.

\section{The Proposal: Proportional Burden-Sharing}

What, then, is to be done? My proposal seeks a refugee protection system that can simultaneously achieve four major objectives: (1) maximization of protection resources; (2) observance of human rights principles; (3) respect for political constraints; and (4) administrative simplicity. Before explaining the proposal, I shall briefly discuss each of these goals.

Maximization of Resources Available for Protection. The system should maximize the total resources available for the genuine protection of refugees. I view this as the paramount objective; its primacy justifies compromising, where necessary, other important but less central goals. Protection resources can be maximized in two ways: by drawing new resources into the system and by better utilizing whatever resources exist. Thus, as many states as possible should participate in the protective system, not just those that possess a

102. See infra text accompanying notes 112-18.

103. By way of comparison, Canada, with one-fourth of Japan's population, resettled more than 136,000 Indochinese. The United States, with twice Japan's population, resettled about 820,000 , but this partly reflected, of course, the special role of the United States in the Vietnam War. See IsAMI TAKEDA, JAPAN'S RESPONSES TO REFUGEES AND POLTICAL ASYLUM-SEEKERS 3, 6 (International Migration Working Paper Series, 1995).

104. See id. at 9,11 tbl.2.

105. See World Refugee Statistics, supra note 97 , at $45-46$ tbls.8, 10. 
particular resource (such as cash, space, or ethnic diversity) or that happen to abut a refugee-producing area. In addition, the system should create incentives to use those resources most effectively. Specifically, it should encourage each state to allocate whatever resources it possesses or can mobilize to the refugeeprotection strategy or strategies-root cause, temporary protection-cumrepatriation, and resettlement-that can be achieved to the greatest extent at the least cost.

Observance of Human Rights Principles. The system should ensure that refugees actually receive the protection to which international human rights law already entitles them. Failing that-and recognizing that the current system often falls far short on this score-their treatment should at least be no worse than it is now.

Respect for Political Constraints. The system should acknowledge the important political constraints that will inevitably continue to shape any meaningful international regime of refugee protection, and its institutions and practices should take due account of those constraints. These constraints are quite formidable, and I have no wish to minimize them. Some of them might seem inimical to more expansive refugee protection; they appear to be decidedly unpromising materials for policy reform. Yet, as I explain below, we can hope to turn three of these constraining conditions-the abiding forces of state sovereignty and self-interest, the growing vulnerability of all states to unwanted refugee influxes, and the diversity of states' traditions and resources for dealing with refugee flows-to some advantage. Indeed, any reform must come to terms with these conditions. A market-oriented approach is peculiarly capable of exploiting them.

Administrative Simplicity. Consistent with its other goals, the system should adopt a decentralized decisionmaking structure, leaving as much initiative as possible to individual states. It should seek to minimize the informational requirements and other transaction costs of the system's decisionmakers.

The proposal consists of five main structural elements: (1) agreement by states in a region on a strong norm that all ought to bear a share of temporary protection and permanent resettlement needs proportionate to their burdenbearing capacity; (2) a process for determining the number of those who need such protection; (3) a set of criteria for allocating this burden among states in the form of quotas; (4) a market in which states can purchase and sell quota compliance obligations; and (5) an international authority to administer the quota system and regulate this market. I shall discuss each of these elements and then identify some of the implementation and enforcement issues that would need to be resolved for the system to work.

In noting these implementation issues, I wish to emphasize what will be obvious to any well-informed reader: Many additional details must be addressed before the scheme can be fully realized. I recognize, of course, that the devil is often in the details. Nevertheless, I think that I am justified in assuming that should agreement be reached on the main outlines of these five structural elements, the rest can, through negotiation, be worked out. Accordingly, I do 
not dwell on the details here.

\section{A. The Principle of Burden-Sharing}

As noted in Part II, international practice in the area of refugee protection reveals the existence of what might be called a weak norm of burden-sharing. A number of international instruments and scholarly analyses proclaim the importance of such a norm and exhort states to observe it. On the more mundane level of international practice, refugee-receiving states have entered into a number of arrangements in recent decades to share the burdens of major refugee crises, notably the CPA in Indochina ${ }^{106}$ and the 1989 Conference on Central American Refugees. ${ }^{107}$

This burden-sharing norm, however, is manifestly weak. In the international instruments in which it can be discerned, the burden-sharing imperative is essentially precatory and hortatory; even its most energetic scholarly exponents like Goodwin-Gill seem to view it more as a moral aspiration than as a legally binding duty on all states. No effort has been mounted to enforce the norm against the numerous states that ignore it. Even in the war in the former Yugoslavia, which was waged with appalling ferocity in the very heart of Europe, the burden of protecting refugees was shared only to a very limited extent, with Croatia, Slovenia, and Germany bearing the brunt of it. ${ }^{108}$

Nevertheless, the moral and prudential foundations for imposing such a duty seem sturdy enough to establish a more robust burden-sharing regime. Joanne Thorburn advances three arguments for this norm, based on human rights, states' self-interest, and the non-refoulement principle:

[F]orcibly moving the people, albeit for protection purposes, would be questionable from a human rights perspective. . . . The statist argument would find support in upholding the right to control admission, as people would not be arriving at the borders of one's own (distant) State because their level of protection would be sufficient in countries close to the State of origin (thanks to financial assistance and logistical support), and because the development and integrity of the first country of asylum would also be supported. However, the primary arguments for burden-sharing lie in support of the principle of non-refoulement . . . and in its necessity as an accompaniment to a firmly established norm of temporary protection. . . . Refoulement, even by proxy, is to be avoided at all costs. ${ }^{109}$

There is another justification for the burden-sharing norm based on the adventitious character of most refugee crises. Refugee flows usually occur with

106. See supra Part III.

107. For a discussion of this burden-sharing arrangement, see Hathaway \& Neve, supra note 22; see also Dennis Gallagher, The Evolution of the Intermational Refugee System, 23 INT'L MIGRATION REv. 579, 590-91 (1989); Rosemarie Rogers, The Future of Refugee Flows and Policies, 26 INT'L MrgRATION REv. $1112,1133-34$ (1992).

108. See Thorburn, supra note 84 (discussing Croatian and Slovenian efforts but unaccountably failing to mention Germany's granting of temporary refuge to hundreds of thousands of Croatians displaced by war there).

109. Id. at $476-77$. 
a suddenness, violence, and magnitude that can swiftly overwhelm the resources of a first-asylum state that is only linked to the flow by an accident of nature-its fortuitous proximity to the source country. In this respect, refugee emergencies resemble natural disasters like earthquakes and tornadoes, calamities as to which the norm of international solidarity and burden-sharing is relatively strong. The relationship of first-asylum states to refugee flows, of course, does not always possess this random, fortuitous character. In some cases, the first-asylum state, far from being an innocent bystander, bears some causal and hence moral responsibility for refugee flows; it may even have fanned or instigated the unrest that unleashed the crisis. The first-asylum state may hope to use the refugees' flight to discredit or destabilize the source country regime (for example, American policy toward Castro's Cuba and Zaire's policy toward Rwanda), or it may have revanchist designs on the source country (for example, Indian and Pakistani policies in Kashmir). Like some societies plagued by certain natural disasters, ${ }^{110}$ first-asylum states sometimes bring refugee crises on themselves.

The possibility that some first-asylum states are complicit in refugee flows should surely be taken into account in designing and administering a reformed system of refugee protection. Indeed, imposing a binding obligation to bear some of the burdens that such a state causes might reduce its propensity to instigate refugee crises in the first place. Even so, the more compelling fact is that first-asylum states ordinarily are not in any morally meaningful sense responsible for their plight. Recognition of this is an important building block in the necessary structure of justification and political support for a norm of universal burden-sharing.

If the innocent helplessness of most first-asylum states is a morally constructive support for this norm, another fact-that different states face somewhat different risks of becoming a first-asylum country-tends to undermine political support for the norm. This risk differential makes it difficult to secure agreement on, much less compliance with, the norm because it reinforces the incentives of relatively insular ${ }^{111}$ and hence low-risk states to avoid burden-sharing by free-riding on the self-interested efforts of the higherrisk states, leaving the latter to bear all of the burdens. This process of defection by low-risk states undermines the viability of any system, like the current one, that relies on voluntary burden-sharing and generates very weak incentives to cooperate. The analogy to the problem of adverse selection in the insurance context-in which those presenting relatively low risks will not participate in insurance pools that charge them average-risk premiums-is apt. No burden-sharing scheme, including the "refugee crisis insurance" approach proposed here, can be effective unless this problem of differential risks is squarely addressed.

110. See supra text accompanying note 3.

111. The word "insular" here simply refers to a condition of relative immunity from large migration flows, whether the barriers to such flows are geographical or geopolitical. 
Generally speaking, there are only two possible solutions to this problem. The first is to increase the estimates by traditionally insular states of their risk of becoming a first-asylum country. The second is to strengthen the other nonrisk related incentives of all states, but especially of those at low risk of refugee flows, to participate in burden-sharing efforts. Both approaches are difficult to implement. Nevertheless, recent developments have rendered them, especially the first, somewhat more promising.

The risk that any state will become a first-asylum country is growing. The economic, spatial, and geopolitical barriers that until recently inhibited mass refugee flows are falling. Virtually all states realize that their territories are potential targets of sudden and possibly large refugee movements-with all of the attendant risks, political and otherwise, that such movements pose to the regime in power. Today, no state is immune; even island nations like Japan and Australia are vulnerable to spasmodic in-migration from the mainland. Ironically, this reality, which is certainly regrettable from the insular states' perspective, presents an opportunity to increase the acceptance of burdensharing.

The change in risk has been most dramatic in Germany and Japan. The Basic Law of Germany expressly provides that it is not a country of immigration, ${ }^{112}$ and the nation's history prior to 1989 was consistent with this tenet. Beginning in 1989, however, a huge influx of asylum seekers into Germany ${ }^{113}$ dramatically challenged this tradition. Immigration and refugee policy has become a central issue in German politics. With restrictionist parties gaining ground, Germany amended its Basic Law in 1993 to limit severely asylum seekers' rights. Despite these efforts, however, the number of asylum seekers in Germany remains quite large. ${ }^{114}$

Like Germany, Japan has only recently begun to consider seriously the need to fashion an immigration and refugee policy. ${ }^{115}$ Although it still receives few refugee claims, they are increasing-as is the number of foreigners, legal and illegal, living in Japan. ${ }^{116}$ Perhaps more important, Japan is experiencing

112. See Rainer Munz \& Ralf Ulrich, Changing Patterns of German Immigration, 1945-1994, in MigRANTS PAST, MigRANTS FUTURE: GeRMANY AND THE UNITED STATES (Klaus Bade \& Myron Weiner eds., forthcoming 1997). The Aussiedler, people of German ancestry whose families have lived in eastern Europe, often for centuries, are not really exceptions, as they are considered German by blood and culture and are permitted to acquire German citizenship more or less automatically upon their return to Germany. See id.

113. Munz and Ulrich provide the statistics. See id.

114. The total in 1994 was 127,000 , well below the 438,000 who applied in 1992. See id.

115. Like Germany's willingness to accept Aussiedlers, Japan now accepts nikkeijin, people of Japanese ancestry living abroad, many of them in South America. See Myron Weiner, Opposing Visions: Migration and Citizenship Policies in Japan and the United States, in TEMPORARY WORKERS OR FUTURE CtTIZENS? JaPAN AND U.S. Migration POLICIES (M. Weiner \& T. Hanami eds., forthcoming 1997).

116. See id. at $10 \mathrm{tbl} .1$. The Japanese Justice Ministry estimated that there were 285,000 foreigners living illegally in Japan in 1995. See Japan's Foreign Residents and the Quest for Expanded Political Rights, JEI REP., July 19, 1996, available in LEXIS, World Library, Allwld File (noting continuing hostility to foreigners and immigration); see also Mayumi Itoh, Japan's Abiding Sakoku Mentality, ORBIS, Mar. 22, 1996, available in 1996 WL 13459521 (noting that, as of January 1995, approximately 1.6 million foreigners resided in Japan). Notwithstanding Japanese resistance to increasing numbers of foreign residents, a looming labor shortage may necessitate more immigration. See Japan's Foreign Residents and the Quest 
growing concerns about potential political convulsions in China, Hong Kong, and North Korea that could quickly send millions of refugees streaming across the short distance that separates Japan from mainland east Asia. ${ }^{117}$

For states like Germany, previously protected by the Iron Curtain but now a country of first asylum on a massive scale, and Japan, no longer protected by its geography from becoming a first-asylum state, the strategic implications of their new vulnerability are immense. No longer can they simply free ride on other states' policies of refugee control and management to protect them from major influxes into their own territories. Indeed, states' new interdependence goes beyond this; historically insular states are now more likely to face refugee flows resulting from the restrictive practices of other states. ${ }^{118}$

Thus, states previously at low risk of becoming first-asylum countries may now find a cooperative strategy far more attractive than they would have only a few years ago. Under this refugee-crisis insurance approach, all states arrange to bear some refugee protection burdens so that none will be saddled with a refugee crisis that it must bear alone. The German and Japanese experiences can serve as vivid lessons for other states that have resisted burden-sharing in the belief that they are still immune from large refugee flows.

The incentives for burden-sharing based on motives other than fear of becoming a first-asylum state remain weak in most regions. The traditional willingness of many sub-Saharan African states, with UNHCR assistance, to offer temporary protection to refugees from neighboring countries is the greatest exception. Pakistan's protection of millions of Afghani refugees during the 1980s is another, although pressure and aid from the United States were instrumental in eliciting this response. Once we move beyond temporary protection to permanent resettlement, as noted above, only Scandinavia, the United States, Canada, and a few other states offer it to a significant number of refugees.

Precisely because the altruistic motives for burden-sharing are so weak, these powerful states have strong reasons to induce others to cooperate by manipulating the formidable carrots and sticks that the powerful states control. In the past, these states, actuated by a combination of humanitarian and deeply self-interested motives, have managed to persuade recalcitrant first-asylum states like Thailand, Hong Kong, and Pakistan to protect temporarily (although the period often proved to be quite protracted) refugees on their territories. ${ }^{119}$

for Expanded Political Rights, supra; Migration Issues in APEC, ASIAN MANAGER, Jan. 1, 1997, available in 1997 WL 10097043.

117. See Weiner, supra note 115; see also Andrew Pollack, Beckoning Foreign Investors, North Korea Opens the Door a Crack, to Capitalism, N.Y. TIMES, Sept. 19, 1996, at D1 ("Some experts fear that North Korea could collapse, sending millions of refugees streaming to South Korea, China and Japan.").

118. This occurred most dramatically whenever Thailand, Hong Kong, and other first-asylum states for Indochinese refugees engaged in pushbacks or announced new restrictions, thereby channeling the refugee flow to Malaysia, Singapore, Japan, Australia, and other potential havens in the region.

119. During the conflict in the former Yugoslavia, the states of the European Union pressed Croatia and Slovenia, first-asylum states for refugees from Bosnia and Herzegovina, to maintain the refugees there rather than diverting them westward. Croatia and Slovenia did so, incurring large fiscal and domestic political costs. See Thorburn, supra note 84 , at 473-76. 
As international economic developments improve industrialized states' leverage over first-asylum states with respect to trade concessions, technical assistance, and access to financial and other support, this approach, which entails the tactical use of political pressure, negotiation, and resource transfers, may bear additional fruit.

The success of a proportional burden-sharing system depends critically on the relatively powerful states' ability to use this leverage more skillfully and forcefully to induce broader participation in the system as refugee flows increase. This is likely to be most practicable in a regionally-organized system. ${ }^{120}$ In any event, one should recall that the current system of protection is equally dependent on the more powerful states exercising leverage and transferring resources to persuade the weaker first-asylum states to harbor refugees. A proportional burden-sharing system can only improve the chances that such influence would be effectively deployed.

This examination of the structure of incentives for refugee burden-sharing does not at all minimize the political obstacles that would impede its implementation, but it provides some hope that the prospects for gaining broader agreement on a more robust burden-sharing norm could improve in the future. The next question is: What should be the actual content of that norm?

The norm should express a principle of fairness in the distribution of refugee protection burdens. Specifically, it should satisfy three criteria of fairness: consent, broad participation, and proportionality.

Consent is essential. No state should be obliged to participate in the burden-sharing scheme unless it voluntarily undertakes to do so. This is a concession not only to practical politics but also to a concern that states both feel a genuine commitment to the enterprise and take responsibility for its success or failure. As the discussion immediately above suggests, a state may consent for a variety of reasons. Its consent is not ordinarily vitiated by the fact that it feels constrained to participate because of pressures exerted by other, more powerful states. States in the international system routinely deploy carrots and sticks in order to influence the decisions of other states and actors; only in the most extreme case would such inducements amount to duress negating consent.

Broad participation in a proportional burden-sharing scheme by consenting states is justified on the basis of each state's membership in an international community, which entails certain minimal rights and obligations defined by international law, including the duty to protect refugees. If the scheme is carried out on a regional basis, as I propose, participation is likely to be widespread, if not universal, within that region because of the more firmly entrenched patterns of intraregional influence and the relative homogeneity of

120. In Africa, the Organization of African Unity might constitute such an organization. Alternatively, South Africa, which is the continent's wealthiest state and has become a major destination for refugees, might lead such an effort. 
wealth and values within regions. ${ }^{121} \mathrm{~A}$ broadly participatory arrangement has several advantages: It minimizes each state's burden by distributing it among many states, and it overcomes the free rider and adverse selection problems by making it very difficult for states to opt out. Consequently, it eliminates the demoralization that participants experience when they perceive that they have been "suckered" by the defection of others. ${ }^{122}$

The proportionality principle is both a norm of fairness and a constraint dictated by political prudence. It demands that a state's share of the burden be limited to its burden-bearing capacity relative to that of all other states in the international community. Rough proportionality is probably essential to both consent and broad participation. Taken together, these three values imply a norm that all states in a region must shoulder some of the burden but that none must shoulder a burden that it cannot in fairness bear.

\section{B. The Needs Assessment Process}

In order to allocate the burden of refugee protection, we must first consider how the overall burden is to be defined, determined, and used as the basis for assigning quotas.

The overall burden is defined as the number of refugees who need to be offered protection-either temporary refuge or permanent resettlement-during a given time period. This number would be calculated by an international agency to be described below, ${ }^{123}$ and would be adjusted as unanticipated refugee emergencies occurred. Suffice it to say here that the agency must be equipped to conduct the necessary investigations, make the requisite factual findings, administer and enforce the quotas, and regulate the quotas market with due regard to changing circumstances.

Two difficult, inevitably controversial issues are embedded in this definition: the number of people seeking protection who are to be treated as refugees, and the number of those refugees who need either temporary protection or permanent resettlement (rather than immediate repatriation). Both issues, however, already arise under the current system and can be resolved, as they are now, through a combination of factual analysis, calculated conceptual ambiguity, and old-fashioned negotiation. As a formal matter, the first issue-refugee status-is a legal one requiring application of the refugee definition under the Convention or its domestic law equivalent. ${ }^{124}$ To varying

121. The qualifier "relative" is important, as the examples of impoverished Haiti and communist Cuba in the North American-Caribbean region demonstrate.

122. As discussed infra in text accompanying notes $136-37$, the principle of broad participation in this context should be subject to two exceptions.

123. See infra Section V.E.

124. The Refugee Act of 1980, 8 U.S.C. \$1101(a)(42) (1994), defines "refugee" as a person with a "well-founded fear of persecution on account of race, religion, nationality, membership in a particular social group, or political opinion." This definition does not include "any person who ordered, incited, assisted, or otherwise participated in the persecution of any person" on account of the same factors. Id. This mirrors the definition in the 1951 Refugee Convention. See 1951 Refugee Convention, supra note 1, art. 
extents in different states, asylum adjudications exhibit such formalism. ${ }^{125}$ In contrast, decisions about which individuals are to be temporarily or permanently protected are relatively ad hoc; they focus less on the legal refugee definition than on the number of people that the protecting state can handle and, in the case of resettlement, on the putative refugee's social and political acceptability to the receiving state. Accordingly, many of those selected for temporary or permanent protection would probably fail to qualify as refugees in the more legalistic setting of asylum adjudication. This practice suggests that the international agency can resolve the issue of refugee status for purposes of this scheme through the relatively informal, low-cost modalities that UNHCR, the first-asylum states, and other states (often with the assistance of NGOs) now use to make protection decisions. ${ }^{126}$

The agency must then calculate a world-wide total of refugees who need temporary protection and a total of those who need permanent resettlement, and then allocate those totals among participating states by assigning a quota to each. The notion of "need" that must inform such a calculation is bound to be controversial. To some extent, need is in the eye of the beholder, as evidenced by the frequent disagreements that now arise over this issue between (and within) UNHCR, potential protecting states, and NGOs. ${ }^{127}$ Under the current system, UNHCR determines how many slots are needed and proceeds to solicit offers from states that it thinks can be persuaded to offer protection. In resisting these entreaties, states may dispute UNHCR's assessment of need, as well as assert their inability to accept more refugees. If further negotiations ensue, the parties may articulate competing conceptions of need; hopefully, some agreement on numbers (if not on the underlying conceptions) may be reached.

Under the proposal, the agency would proceed in a similar fashion. The stakes in its needs assessments, however, would be much higher than they are now because the assessments would generate the overall numbers to determine each state's binding quota. For this reason, it would be essential for the agency to render its needs assessments more transparent and to establish procedures enabling states to contest the findings on which their shares would be premised.

1, para. A(2). Section 604 of IRIRA in effect narrows the refugee definition by barring several additional categories of aliens from applying for asylum. See IIRIRA, Pub. L. No. 104-132, § 604, 110 Stat. 1214 (amending 8 U.S.C. $\S 1158$ ).

125. The formalism of asylum procedures differs considerably among countries. The U.S. system is by far the most formal. See David Martin, The Obstacles to Effective Internal Enforcement of the Immigration Laws in the United States, in IMMIGRATION ADMISSIONS: THE SEARCH FOR WORKABLE POLICIES IN GERMANY AND THE UNITED STATES, supra note 95.

126. The contrast between the resources expended on formal asylum adjudication and those expended on actual refugee protection is striking. See Hathaway \& Neve, supra note 22.

127. See Refugees in Eastern Zaire and Rwanda: Hearings Before the House Comm. on Int'l Relations, Subcomm. on Int'l Operations and Human Rights, 105th Cong. (1996), available in LEXIS, Legis Library, Cngtst File (statement of Roger P. Winter, Dir. U.S. Comm. for Refugees) (noting wide disparities in refugee numbers); Thomas W. Lippman, Govemments, Aid Groups Divided over Refugee Crisis in Zaire, WASH. POST, Nov. 22, 1996, at A41 ("Some relief organizations accused the Clinton administration of playing down the crisis to wiggle out of its commitment to send troops for an international military rescue mission. But American officials said that numbers compiled by the U.N. High Commissioner for Refugees (UNHCR) were exaggerated."). 
Both needs assessments and procedures for challenging them are common in many areas of social policy and administrative law. Their design in the protection context should pose no special difficulties, other than the political ones owing to the weaker enforcement mechanisms in the international realm and the delays that such challenges might entail. The current system elides enforcement problems, of course, but only because it relies entirely on voluntary protection offers extended by a relatively small number of states.

The agency's determination as to how many people need only temporary protection and how many instead need resettlement is, of course, a very difficult one, requiring much information that is hard to obtain and even harder to verify, as well as predictions that may be little more than educated guesses. For the same reason, the line between temporary and permanent refuge is not easily maintained; as with the TPS Salvadorans, ${ }^{128}$ many refugees cannot be repatriated by the protecting state despite its energetic efforts to do so.

Again, it is important to recognize that the current system must make the same kinds of difficult determinations so that UNHCR can plan the allocation of its limited resources and negotiate with potential protecting states. An additional advantage of a burden-sharing system, however, is that those states-fearing that erroneous predictions and determinations could leave them with more (or more permanent) refugees than they initially bargained for-would have strong incentives to ensure that the determinations are accurate, that other participating states bear their fair shares and minimize the necessity for permanent resettlement, and, most importantly, that temporary protection does not become permanent without the state's genuine consent.

\section{The Criteria for Allocating the Protection Burden}

In order to implement the proportionality principle discussed earlier, the quota should be based exclusively on what I shall call the protection criterion, which is designed to measure the capacity of the state in question to provide refugees with the most minimal safeguards and amenities to which they are entitled under the Refugee Convention. They primarily include food, clothing, shelter, and physical security. ${ }^{129}$

In the kind of regional, consensual burden-sharing scheme that I propose, the participating states would of course be free to adopt whatever protection criterion (or criteria) they preferred. Nevertheless, national wealth is a compelling index. Protective capacity is largely, though not exclusively, a function of national wealth. Human rights law aspires to assure refugees the

128. See supra text accompanying notes 90-92.

129. I emphasize the importance of the minimality of these safeguards and amenities to any realistic scheme of burden-sharing and protection. Although the ultimate goal is to integrate fully resettled refugees into the host society once it is concluded that safe repatriation cannot be effected, the initial conditions of maintenance should maximize the number of people who can be minimally protected for a given expenditure, rather than protecting fewer refugees at higher levels of amenity. Protection implies safety before comfort. 
most basic necessities of life and personal security, and a state's wealth is the single best surrogate for those factors that actually determine its ability to provide these necessities, directly or indirectly. National wealth is also readily quantifiable, albeit not without some controversy around the edges, ${ }^{130}$ and it is a factor so closely related to national prestige that states are unlikely to succeed in minimizing it in a strategic effort to reduce their share of refugee burdens.

Other plausible criteria lack the administrative advantages of a wealth criterion. Consider the example of assimilative capacity. ${ }^{131}$ One might want states' quotas to reflect their different propensities to assimilate refugees and other foreigners. The notion of assimilation, however, is notoriously hard to define or gauge objectively. ${ }^{132}$ Indeed, the scholars who study it disagree strenuously about why, how, and when it occurs. ${ }^{133}$ There are also normative objections to an assimilation criterion. Although it is highly desirable for states to facilitate affirmatively the integration of foreigners to whom they offer permanent resettlement, states are under no international legal duty to assure them full integration; states are only obligated to provide basic safeguards such as the right to work and to be free from discrimination. ${ }^{134}$ Full assimilation, moreover, is fundamentally incompatible with a regime of temporary protection-relief that states will only provide if they believe that it will terminate within a reasonably short period of time and thus before full integration occurs. As noted in Part IV, maintaining the credibility of temporary protection is essential to the viability of the protection system as a whole. Finally, a criterion that would enlarge states' quotas if they succeed in assimilating foreigners would perversely punish states for their openness and generosity.

The attractiveness of national wealth as the sole criterion for assigning refugee protection quotas is especially great in a system like the one I propose here, which would allow a state to pay other states to provide those protection services that it cannot or will not provide on its own territory. For this reason, a state's wealth should probably trump other objective factors such as

130. National wealth can be measured in different ways. Some of the many indices include gross national product, per capita national product, GNP adjusted for quality-of-life or social indicators, potential wealth, etc.

131. Another example-consideration of a state's own responsibility for refugee flows-would also be very difficult to apply. Such a criterion would be confounded by all of the notorious complexities and indeterminacies of social process, historical causation, international morality, and international politics.

132. One might try to devise measures of assimilation based on indices of ethnic conflict within particular societies, patterns of in- and out-migration, levels of political and social participation by minority groups, naturalization rates, and the like. Even if such measures could be compiled, they would be so crude as to be unacceptable to the states involved.

133. See, e.g., Richard D. Alba, Assimilation, Exclusion, or Neither? Models of Incorporation of Immigrants in the United States, in THE INTEGRATION OF MIGRANTS IN THE UNITED STATES AND GERMANY (Peter Schuck \& Rainer Munz eds., forthcoming 1997) (discussing different models).

134. See 1951 Refugee Convention, supra note 1, art. 3 ("The Contracting States shall apply the provisions of this Convention to refugees without discrimination as to race, religion or country of origin."). Most rights conferred by the Convention are not mandatory upon contracting states, see supra note 21 and accompanying text, and contracting states are only required "as far as possible" to "facilitate the assimilation and naturalization of refugees," 1951 Refugee Convention, supra note 1 , art. 34. This fact reduces the force of the displacement of voluntarism objection. See infra Part VI. 
population density and land mass. ${ }^{135}$ Although these factors may well affect the ease with which a state can protect or resettle refugees on its own territory, these factors are probably best taken into account as they are reflected in the prices that states are willing to pay to transfer their burden to other states. For example, Malaysia and Singapore are countries of relatively great wealth but with high population densities, small land mass, and severe ethnic tensions that refugees might further inflame. These countries would be assigned large quotas but would probably offer a high price to shift the protection burden elsewhere.

Two exemptions from the quota system should be provided, and neither is likely to be controversial in practice. First, no quota should be assigned to a state that engages in systematic violations of human rights, nor should such states be permitted to purchase other states' quotas. Although the reason for this principle is obvious, some objections to it are also obvious. Applying the criterion in a world in which the number of repressive states remains tragically large would require some elusive and morally dubious distinctions. A few relatively easy cases exist (Iraq and North Korea, for example), but the gradations of brutality between these and many other regimes are subtle, and line-drawing will surely be both difficult and controversial. Furthermore, that states will view participation in the protection quota system as a burden rather than a benefit creates a perverse incentive: The exemption, by relieving states of a burden, could seem to reward human rights violations and hence encourage them. Although a state could only qualify for the exemption by being labeled as a human rights violator, this obloquy, which already attaches to such states, has manifestly failed to reform their odious conduct and is even less likely to do so when asserted as part of a refugee protection scheme.

In the context of the regional, consensual arrangement that I propose, this perverse incentive would be irrelevant. In such a scheme, the regional powers would have to agree on which states would participate and under what conditions. The regional leaders would surely be under great internal and external pressure to exclude the worst human rights violators. ${ }^{136}$ Dissenting

135. Multi-factor criteria could certainly be devised. In connection with the conflict in the former Yugoslavia, for example, Germany proposed a formula for allocating protection burdens among the European Union states. According to Joanne Thorburn, the proposal was

based on the size of the population of Member States, the size of their territory and the amount of their Gross Domestic Product, all as a percentage of the Union total, leading to figures guiding the percentage number of people from a mass influx of displaced persons which each State should take. This indicative figure would be modified according to the Member State's contribution to peace-keeping forces and its particular use of foreign and security policy measures in the country of origin. The reaction from other Member States was sceptical, not surprisingly since the proposing State is the one whose burden would be relieved by the institution of such a mechanism, whereas others would find themselves faced with more persons in need of protection.

Thorburn, supra note 84 , at 476 (footnote omitted).

136. It is true, as Joan Fitzpatrick observes, that even human rights violators "may in fact be safe harbors for certain groups of refugees." Letter from Joan Fitzpatrick, Professor, University of Washington, to author 1 (June 27, 1996) (on file with author). She mentions Zaire and the Rwandan Hutu, and Iran and the Iraqi Kurds as examples. Id. Whether such states could participate would be a matter for the regional groups to resolve. 
states need not join, and the rogue states themselves would hardly complain about being exempted from burden-sharing obligations.

The second exception should be for states whose wealth falls below some minimal level, as determined by international agencies. ${ }^{137}$ Again, the justification is obvious: If such states cannot assure basic sustenance to their own people, they can hardly provide effective protection to strangers. This second exemption can overlap with the first, as demonstrated by the example of Haiti, which is both destitute and a persistent human rights violator.

Apart from these two exemptions, temporary adjustments to a country's wealth-driven quota may be the best that the system can manage by way of further refining the criterion. Certain exigent conditions substantially impairing a state's ability to accept or pay for refugee protection-for example, a state of war or natural disaster-might justify a temporary quota reduction or even a suspension. For similar reasons, the system should reduce a state's quota to reflect the number of refugees who are already on its territory and to whom it offers either asylum or temporary protection of a specified duration. Such a credit, and the incentives that it creates for the receiving state, would also minimize the emotional and economic costs of moving refugees, who have already suffered at least one dislocation, from an asylum state to another state. ${ }^{138}$

If such temporary quota adjustments were permitted, of course, states would press hard to obtain relief under them. Each adjustment, moreover, would entail vexing definitional and measurement problems. ${ }^{139}$ Refinement of the quota system through adjustments of this kind, then, would inevitably increase the administrative complexity of the system.

\section{A Market in Refugee Protection Quotas}

Would states be interested in paying others to protect refugees? The short answer is that they already are doing so. In some refugee crises like Rwanda,

137. The United Nations Development Programme compiles cross-national indices on wealth in its Human Development Index. U.N. Dev. Programme, Human Development RePort 15-22 (1995) [hereinafter HUMAN DEVELOPMENT REPORT] (measuring factors such as life expectancy at birth, educational attainment, including adult literacy and school enrollment, and income); see also Barbara Crosette, U.N. Documents Inequities for Women as World Forum Nears, N.Y. TIMES, Aug. 18, 1995, at A3.

138. The regional character of the proposed burden-sharing scheme encourages consideration of such factors. For example, if refugees are to be temporarily protected or permanently resettled, it is clearly preferable to do so in the region from which they came, other things being equal. The operation of the quotas market is likely to reinforce the salience of this neighborhood factor by providing a premium to states for taking refugees who can more easily be returned once the need for protection ceases. Robert Ellickson has suggested a higher quota for neighboring states on the theory that they are likely to have the greatest influence over most of the conditions that spawn refugee crises nearby; increasing their quotas to reflect this factor, he argues, will strengthen their incentives to prevent those conditions from producing refugee flows. Interview with Robert C. Ellickson, Professor of Law, Yale Law School, in New Haven, Conn. (Feb. 19, 1996).

139. For example, crediting a state's quota to reflect its protection of those refugees who are already on its territory might require distinguishing between refugees and ordinary immigrants. In countries like the United States, drawing this distinction often requires a complex, costly adjudication. Even then it is somewhat arbitrary. 
some relatively wealthy states contribute funds to the first-asylum state to support its protection efforts in situ. Although these delegations of protection resources and responsibilities are certainly better than nothing, they suffer from a number of limitations. The delegation transactions are inevitably ad hoc, with each transaction having to be organized and coordinated by UNHCR, a dedicated but sluggish and highly politicized bureaucracy. They invite strategic behavior by states with conflicting interests hoping to free ride on the efforts of others.

A market system cannot eliminate these conditions, but it can hope to leverage certain constraints on refugee protection into an improved system. Just as increasing refugee flows, by exposing even traditionally insular states to the risk of sudden influxes, might encourage them to participate in the system of refugee protection, a market system might transform two other real-world constraints into important refugee policy virtues. First, state actors are motivated largely by their perceptions of national self-interest, broadly defined; they are unlikely to adopt humanitarian policies that are inconsistent with those perceptions. Second, states vary enormously in both the attitudes and the resources that they bring to refugee policy. A few states willingly devote substantial resources to refugee protection while other states do little but pass the buck.

Although reformers cannot count on changing either states' motivations or states' heterogeneity, they can devise mechanisms to guide states' self-interest into channels conducive to humanitarian goals. These mechanisms can encourage states to exploit their heterogeneity through exchanges that serve both their self-interest and the public interest in refugee protection. A properly regulated market in refugee protection quotas promises to accomplish both of these ends.

Once a state receives its quota, it must decide whether it will discharge it by offering protection to refugees (either temporary safe haven or permanent resettlement) on its own territory and, if so, which form of protection it will provide. It must then identify the particular refugees whom it will protect. In addition to domestic political considerations, this selection process now entails a number of interactions-interviews, investigations, consultations, and negotiations-with UNHCR, other potential receiving states, the first-asylum state, NGOs, and of course the particular refugees who are candidates for protection.

Under my proposal, the state would have an additional option. Rather than protect the quota refugees itself (presumably, but not necessarily, on its own territory), it could transfer part or all of its quota obligation to another state ${ }^{140}$ in a voluntary, public transaction. In effect, the transferor state would pay the transferee state, which might not be a member of the regional burden-sharing system. The transferor state would be purchasing a discharge of its obligation from the transferee. The payment presumably would take the form of cash, but

140. Or states, since the quota might be fractionated for purposes of trading. 
it could, in principle, be any resources that the transferee values enough to accept: credit, commodities, development assistance, technical advice, weapons, ${ }^{141}$ political support, or some combination of these assets.

At first blush, it might seem preferable simply to create a centrally administered refugee protection fund into which each state would be obliged to pay a sum equal to its share under the protection criterion. The central authority would then contract with individual states for protection services. This approach, however, entails at least two important disadvantages. First, it would restrict the acceptable currency of trade to cash, thereby limiting the number and flexibility of possible transactions. The proposed system, in contrast, would permit a transferee state to accept not only cash but also any other resources, including political support and other hard-to-monetize assets, that it values more than cash. Second, a centralized system would be more complex and involve higher transaction costs than a more decentralized system in which state-to-state negotiations and transactions would predominate. For these reasons, states are more likely to accept the burden-sharing norm if it is effectuated through a market system.

Why might states enter into such transactions? As in any voluntary exchange, the parties will only do so if the exchange makes each of them better off, and it is entirely possible that no deals would in fact be struck. Even in this case, refugee protection would still be better off than under the existing system because of the quota state's commitment to its initial quota. Here, the transferor can only induce the transferee to accept the transferor's obligation by paying the transferee enough to compensate it for the additional burden of accepting the transferor's quota. This is precisely why interstate heterogeneity, with respect to both their attitudes toward refugees and their resources for dealing with a refugee burden, can be a policy virtue.

Consider the example of Japan. Any regional system that included Japan would certainly assign it a large quota; after all, its people are the eighth wealthiest per capita in the world and the wealthiest in Asia. ${ }^{142}$ With a remarkably homogeneous population and no tradition of refugee protection, immigration, or assimilation of foreigners, Japan would presumably be eager to purchase a discharge of its large protection obligation from another country-perhaps Australia, New Zealand, or another Pacific Rim state-and at a high price, reflecting both its high cost of living and its determination to maintain its ethnic homogeneity. ${ }^{143}$

Ethnically homogeneous, densely populated, and somewhat xenophobic states like Japan are not the only ones that might be willing to pay to be relieved

141. The transfer of weapons would be subject, of course, to nonproliferation requirements.

142. See HUMAN DEVELOPMENT REPORT, supra note 137, at 19 tbl.1.1. Some small oil countries also have extremely high per capita wealth. Qatar and the United Arab Emirates ranked third and fourth, respectively, in real GDP per capita in 1992. See id. at 20 tbl.1.2.

143. See, e.g., Sheryl DuWunn, Japan Worries About a Trend: Crime by Chinese, N.Y.TIMES, Mar. 12,1997 , at A4 (noting that large relative increase in illegal immigrants from China and immigrant-related crime "shakes the very foundation of the Japanese government"). 
of their burdens. The United States in effect did this in response to the 1994 exodus from Cuba when it persuaded Panama and several islands in the region to accept about 9000 refugees, albeit only on a temporary basis. ${ }^{144}$ Canada, Australia, New Zealand, Scandinavia, many European Union nations, Brazil, and other high-quota states with low population densities and a tradition of receiving and assimilating refugees and other immigrants would also be competing in regional or larger markets.

Like all other immigrant-receiving societies, these states are now facing strong public pressures to admit fewer refugees and immigrants. A quotas market would offer them a flexible solution to this political dilemma. It would enable them to respond to these restrictionist pressures not by reducing the level of refugee protection that their humanitarian traditions demand but by actually increasing it. This is because the high-quota states that would likely be purchasers of quota discharges also have high prices for most commodities, products, and services that refugees need. The costs per refugee are bound to be much higher in these states than almost anywhere else in the world. Refugees are entitled only to basic protection from persecution, not residence in the society of their choice. Human rights policy should seek neither more nor less than this.

By facilitating voluntary trades, moreover, the quota market could reduce the overall cost of the refugee protection system, giving it more "bang for the buck." First, it would tend to move protection programs from higher-cost states to lower-cost ones, enabling more refugees to be protected for any given resource level than under the existing system. Second, by increasing the number of states in a region that participate in the refugee protection system (as either buyers or sellers of discharge quotas), the system would reflect in the quota's market price the costs of shifting refugees from the state of first asylum to another place; hence, those costs would be minimized. In this way, high-quota states would seek to discharge their quotas by paying states of first asylum or neighbors of such states to protect those refugees where they are already located. Third, the quota price would reflect the risk that protection, initially meant to be temporary, will evolve into the more costly situations of long-term custody and permanent resettlement. Thus, transferor states, wishing to minimize the price they must pay to induce transferees to assume their burden, would have an interest in maintaining the integrity of temporary protection, which in turn is essential to the viability of any voluntary refugee protection system, including the current one.

The other side of the market-potential transferee states-should be reasonably crowded. All states want, and most desperately need, the hard currency that the high-quota states would presumably use to pay for their quota discharges, although transferee states might also value other forms of payment. Some potential transferee states have not been notably receptive to refugees but

144. See Koh, supra note 85, at 155. According to Bronson McKinley, a senior State Department official involved in negotiating the agreement with Panama, the cost to the United States was quite high. 
already have ethnically diverse populations and may have vast empty spaces (and residential controls) for temporary protection or resettlement. Russia and Brazil are examples. Even a wealthy state with a sizable quota of its own might nevertheless be willing to accept some additional refugees, especially if its costs of doing so are fully, or perhaps even more than fully, covered by a transferor's payment. The state's motive might be humanitarian, ideological, ethnic, or geopolitical, rather than, or in addition to, the mercenary pursuit of hard currency. ${ }^{145}$

A potential source of uncertainty in a quotas market is the identity of the particular refugees who comprise a state's tradable quota. ${ }^{146}$ Ordinarily, states do not accept refugees for temporary protection or resettlement until they have interviewed them and compiled a more or less particularized dossier. Under the proposed system, this information might be even more valuable; several states, not just one, would want it in order to decide whether and at what price to trade.

States considering whether to buy or sell quotas would seek to use such information to predict the economic, social, and political effects of such a trade. Just as states under the current system usually give careful consideration to precisely which individuals or groups they are being asked to protect, states under the proposal would pay particular attention to whether they have historical ties to certain refugees based on language, ethnicity, or other relationships to the receiving state. They will value whatever data on the refugees' social class, level of education, ethnicity, age, religion, family status, and any other demographic variables that may help them predict how quickly those refugees will assimilate, how productive they will be, which public services they will consume, and so forth. If states value such information but cannot obtain it, their costs and risks of trading will increase.

Amassing the information should not be too costly. First-asylum states already gather enough data to determine refugee status or otherwise decide what to do with the individual. Moreover, no state will seek information that is not worth the cost of gathering and assessing it. Refugees may want to limit uncontrolled access to personal information about themselves, fearing not only loss of privacy but also reprisals by their state of origin. These concerns can probably be met through confidentiality requirements. ${ }^{147}$

Another problem-that such information lends itself to discriminatory group judgments by receiving states-seems inescapable. Certainly it exists under the current system. A state's willingness to accept refugees depends in

145. Germany's willingness to accept hundreds of thousands of Croatian refugees, for example, is explicable in these terms. If the transaction were "identity-blind," however, certain motivations such as ethnic commonality would be weakened. This issue is discussed below.

146. The problem arises, of course, with respect to two groups of refugees-those who would comprise the quota initially assigned to a state and those who would comprise the quotas for which a potential transferee state might be willing to bargain. An analogy to poorly specified property rights is apt.

147. U.S. law protects the confidentiality of asylum applicants by limiting disclosure of the asylum application and identifying details. See 8 C.F.R. $\$ 208.6$ (1995). Presumably, regional burden-sharing arrangements could provide similar safeguards. 
part on how it evaluates the refugees' prospects for early return or, if resettlement is necessary, for assimilation and productivity in the receiving state. These evaluations turn on the states' assessments of the demographic characteristics of different racial and ethnic groups and on the states' historical ties to those groups.

Although such assessments invite prejudicial and discriminatory judgments that would be odious in any other context, it is hard to see how they can be avoided here. Virtually every state that admits immigrants discriminates on the basis of national origin (source country), social class (skill or educational level), and ethnicity (family, linguistic, or cultural ties). The relatively few states that agree to protect refugees engage in a discriminatory selection process in which they choose how many refugees, and which ones, they will accept. ${ }^{148}$ The haggling is particularly intense where permanent resettlement, with its higher stakes, is proposed.

The political reality is that states would be even more reluctant to accept refugees for protection if they could not pick and choose in this fashion. Perhaps they could be induced to agree on a "blind" allocation process behind a Rawlsian veil of ignorance. Would this be preferable? It seems doubtful. The fact is that certain affinities-religious, linguistic, ethnic, and occupational-between a receiving state and refugees tend to facilitate larger quotas, more generous treatment (in the case of temporary protection), and more rapid assimilation (in the case of resettlement). The proposed burdensharing system seeks to make a virtue of this necessity by using a quotas market, in which such affinities would be reflected in quota prices, to attract more states and more resources into the vital work of refugee protection.

This issue probably cannot be resolved without further analysis and experience. The most important empirical question is how specific the information about the refugees in the quota must be in order to meet the demands of potential trading states. The answer depends largely on the relative costs and benefits of obtaining more specific information. Some states might be satisfied with broad demographic data on group composition; others might insist on the kind of refugee-specific identifying information that raises confidentiality and safety concerns. Such preferences probably vary from state to state. ${ }^{149} \mathrm{~A}$ state's demand for refugee-specific information will also be affected by whether it offers only temporary protection, in which case particularized information is less important, or permanent resettlement, in which case the state will usually require it.

The problem of discriminatory refugee selection is not a new one, and the proposed burden-sharing scheme should not be faulted for failing to offer a neat

148. At the time of this writing, the U.S. government is considering the resettlement of Kurdish refugees from northern Iraq on the basis of whether they previously worked for the United States. See Steven Lee Myers, U.S. To Help Free Refugees in Iraq, N.Y. TIMES, Sept. 13, 1996, at A1.

149. States may differ in the extent to which they view refugee resettlement as a type of immigration program in which they make judgments on a highly individualized basis about refugees' assimilability, as distinguished from more generalized, categorical judgments. 
solution that earlier efforts could not manage to devise. The CPA, the most comprehensive burden-sharing program yet established, allocated refugees through a process of intensive negotiation among the participating states in which certain demographic affinities were informally recognized as legitimate bases for assigning particular groups of refugees to one state rather than to another. Although all states would prefer that "their" refugees possess such affinities, some states were more insistent on them than others. In the end, the United States was perhaps the least insistent, accepting many refugees whom other states would not take. ${ }^{150}$

\section{E. An International Authority}

The proposal entails certain tasks that only an agency can perform. The agency must gather information about refugee protection needs, assign quotas to the states, develop policies to facilitate the market in quotas, disseminate information about market transactions, and deploy whatever authority the states grant it (or it can muster informally) to ensure that refugees' rights under international law are fully protected.

Although the states that would establish burden-sharing schemes might wish to assign these tasks to a new or existing regional agency, UNHCR is an obvious candidate to carry them out. UNHCR does not now assign quotas or supervise a market, but it already performs other functions that have allowed it to amass enormous expertise in refugee protection. There are good reasons, therefore, to entrust the quota and market responsibilities to UNHCR and to provide it with the resources and authority necessary to execute them. ${ }^{151}$ There are also reasons to expect that UNHCR's effectiveness would improve under the proposed scheme, as the participating states would have strong incentives to strengthen UNHCR's capacity by providing it with adequate resources and political support. ${ }^{152}$

The agency should disseminate information about market transactions, but it need not otherwise devote much attention to policing them. Sovereign states should be presumed to be fully capable of protecting their own transactional interests in this market. What states cannot be relied upon to protect, however, are the interests of the refugees who enter their territory, which to some degree conflict with the states' interests in minimizing the burdens of refugee admissions. Although the states must retain the primary responsibility for the welfare of those refugees, the agency has crucial roles of advocacy and perhaps enforcement in pressing the states to observe international legal principles governing the treatment of refugees. Precisely how the agency plays these roles

150. See supra text accompanying notes $62-64$.

151. The coordinating role of intergoverumental agencies, notably UNHCR and UNDP, has been very important to the success of burden-sharing arrangements. See Hathaway \& Neve, supra note 22.

152. This was the case during the CPA, when the United States and other participating states extended UNHCR's responsibilities to include establishing and administering holding camps. See Eagleburger, supra note 48 , at $69-70$. 
depends in part on the formal authority that the agency receives from the states and the informal leverage that it can generate.

In addition, the agency must help to resolve certain policy issues surrounding the structure and performance of the quotas market. Two such issues-applications for temporary quota adjustments and the specificity of the information about refugees-have already been discussed. Others are certain to arise. The transactions themselves, however, should be negotiated and effectuated state-to-state, not through the agency as intermediary.

\section{A Response to (ANTiCIPATED) CRitics}

A number of objections to a market in refugee-protection quotas can be readily anticipated. In this part, I respond to the three most likely ones: (1) unworkability; (2) quality of protection; and (3) commodification. Each of these objections raises legitimate concerns. Most of them can be met in the design of the new system. For a few, doubts do remain. Again, however, these doubts apply at least as strongly to the existing system.

\section{A. The Unworkability Objection}

The first objection proceeds from the argument that the scheme is politically unacceptable and thus practically unworkable. Agreement among states is necessary to establish the system, yet states, so the argument goes, have no incentive to conclude such an agreement because a quota system would limit the freedom of action that they now enjoy and impose additional burdens on them. If states actually had the desire to create such a system, they would already have done so. Furthermore, a system of quotas would be complex and difficult to administer. Finally, it would be impossible to enforce such a system in the absence of a central entity possessing the requisite legal authority and coercive power. No such entity exists in the international sphere. This unworkability objection really consists of three somewhat distinct points concerning incentives, administrability, and enforceability. I have already discussed these to some extent. I shall consider them now in greater detail.

Incentives. The logic of the claim about incentives is contingent on the circumstances specified by the observer. Any structure of incentives is inevitably contextual; a function of the conditions and choices that confront the decisionmaker at a particular point in time.

I have shown that the refugee context is indeed changing in ways that are altering the objective risks that states face, their perceptions about such risks, and their policy choices. The key change is the apparently permanent refugee crisis. No state is wholly immune from this crisis, which is already affecting how states perceive their risks of becoming a country of first asylum. These new perceptions, I suggest, should make states more receptive than they have previously been to a form of burden-sharing, a strategy that I have termed refugee crisis insurance. Today, even (or perhaps especially) a traditionally 
insular state might rationally prefer to agree in advance to accept a limited number of refugees in exchange for an assurance that other states will relieve it of any additional burden in the event of a refugee emergency that suddenly transforms it into a first-asylum country. Finally, as discussed below, ${ }^{153}$ the states with the greatest stakes in a broader distribution of refugee protection burdens are precisely the ones that possess the largest stock of carrots and sticks.

Thus, the incentives to support such a burden-sharing strategy are now in place. Whether states will in fact act on them, of course, is an entirely different question; one must never underestimate the durability of old perceptions and policies. Nevertheless, the refugee pressures that have been building on some traditionally insular states like Germany, Japan, Australia, and New Zealand, and the growing sense of urgency-even crisis-among some of these states is evidence that the new incentives are affecting state behavior. The rise of at least embryonic regional refugee burden-sharing (and burden-avoiding) arrangements in Europe ${ }^{154}$ and North America provides additional evidence of such a transformation. ${ }^{155}$

Administrability. It is certainly true that quota systems can be difficult to operate. They require an administrative agency to resolve a number of methodological, empirical, and normative questions, to implement the system in the face of many practical and political obstacles, and to make adjustments to accommodate constantly changing conditions. That the scheme would be consensual at its inception-that states would participate only if it served their interests-would reduce, but not eliminate, these obstacles.

The best evidence of such a system's administrability would be the operation of analogous schemes in other areas of public policy. During the last decade, many proposals have been made in which a regulatory authority would permit regulated entities to trade entitlements or obligations as a way to improve the regulated activity's allocative efficiency. ${ }^{156} \mathrm{~A}$ few of these proposals would necessitate international agreements. ${ }^{157} \mathrm{My}$ proposal for tradable refugee-protection quotas draws on this approach.

Unfortunately, only a few such trading schemes have yet progressed much

153. See infra text accompanying notes 168-69.

154. See 1985 Schengen Agreement, supra note 8; see also Reerman, supra note 95.

155. See Hathaway \& Neve, supra note 22.

156. For some examples of this approach, see Michael Klausner, Market Failure and Community Investment: A Market-Oriented Alternative to the Community Reinvestment Act, 143 U. PA. L. REV. 1561, 1580-92 (1995) (proposing tradable community investment obligations); Edmund L. Andrews, F.C.C. Plan, with a Twist, To Require Educational TV, N.Y. TMES, Apr. 1, 1995, at 38 (proposing tradable children's educational programming requirements); Peter Passell, A Venerable Peanut Subsidy May Be Target of Republicans, N.Y. TIMES, Dec. 1, 1994, at D2 (noting plan to make peanut marketing quotas tradable within counties); Peter Passell, Big Government and the Big 3 Pass the Air Pollution Buck, N.Y. TimEs, Oct. 20, 1994, at D2 (proposing tradable auto emission reduction obligations); Peter Passell, One Answer to Overfishing: Privatize the Fisheries, N.Y. TIMEs, May 11, 1995, at D2 (planning to create fishing rights quotas).

157. See, e.g., Richard B. Stewart \& Jonathan B. Wiener, The Comprehensive Approach to Global Climate Policy: Issues of Design and Practicality, 9 ARIZ. J. INT'L \& CoMP. L. 83 (1992) (proposing to reduce greenhouse gases). 
beyond the brainstorming stage, and none of them is either fully developed or entirely analogous to what I am proposing here. Nevertheless, two marketoriented schemes of this general kind, New Jersey's "fair share" affordable housing program and emissions trading under the Clear Air Act, are of some interest to refugee-policy reformers because they rely on assigned quotas, allow trading of those quotas, and have already been implemented to some extent.

The New Jersey program grew out of an earlier decision by the state supreme court in the seminal Mount Laurel litigation. ${ }^{158}$ There, the court held that the state constitution required each municipality in the state to provide its fair share of affordable housing to people of low and moderate income. The state subsequently enacted a statute ${ }^{159}$ to systematize these obligations and established a Council on Affordable Housing to implement the fair-share scheme. As part of this scheme, now municipalities may, under certain circumstances, enter into regional contribution agreements (RCAs) in which municipality $A$ pays municipality $B$ to discharge up to $50 \%$ of $A$ 's fair-share obligation. RCAs, it was hoped, would encourage rehabilitation of the existing and often substandard housing stock in the central cities. ${ }^{160}$

As implemented, the New Jersey scheme can hardly be said to be an unqualified success; commentators have given it mixed reviews, including some harsh criticism. ${ }^{161}$ Although a number of RCAs have been concluded, they apparently provide for only a modest number of housing units, ${ }^{162}$ and this seems to be true of the fair share program as a whole. Much of the difficulty stems from disputes over the fair shares and from the ease with which developers and municipalities can circumvent program requirements. ${ }^{163}$

Another market-oriented system that is already in place is emissions trading under the 1990 Clear Air Act amendments. ${ }^{164}$ Under this program, utilities that reduce their emissions below a prescribed level may, under certain circumstances, either "bank" the excess reductions for their own future use or sell them as allowances to other utilities that face higher abatement costs. As with New Jersey's fair share program, the reviews of emissions trading are mixed. In contrast to the New Jersey program, however, virtually all commentators endorse the policy of emissions trading and agree that the savings in regulatory compliance costs have already been substantial. The main criticism seems to be that the program has failed to realize its full potential,

158. Southern Burlington County NAACP y. Township of Mount Laurel, 456 A.2d 390 (N.J. 1983); Southern Burlington County NAACP v. Township of Mount Laurel, 336 A.2d 713 (N.J. 1975).

159. Fair Housing Act of 1985, N.J. STAT. ANN. §§ 52:27D-301 to -329 (West 1986 \& Supp. 1992).

160. See JesSe DUKEMINIER \& JAMES I. KRIER, PROPERTY 1126 (3d ed. 1993).

161. Id. at 1127-28 (discussing studies in summary fashion).

162. See NEW JERSEY COUNCL ON AFFORDABLE HOUS., STATUS OF MUNICIPALITIES, 1989-1999 (1997).

163. For a discussion of the outcome of the Mount Laurel case, see Ronald Smothers, After Landmark Ruling, Slow and Painful Progress, N.Y. TIMES, Mar. 3, 1997, at B1; Ronald Smothers, Decades Later, Town Considers Housing Plan for the Poor, N.Y. TIMES, Mar. 3, 1997, at B5; Ronald Smothers, Mt. Laurel Votes To Build Homes for the Poor, N.Y. TMES, Apr. 12, 1997, at B1.

164. 1990 Amendments to Clean Air Act, Pub. L. No. 101-549, \$§ 401-413, 104 Stat. 2399, 2584-635 (codified at 42 U.S.C. \$ 7651 (1994)). 
largely because of market and regulatory uncertainty that discourages more extensive trading. ${ }^{165}$ Efforts are afoot to broaden the use of emissions-trading mechanisms-extending into the international arena. ${ }^{166}$

It is hard to know precisely what lessons, if any, refugee-policy reformers should draw from the experiences of the domestic housing and emissions control programs and the emerging international environmental accords. These programs are similar to a refigee-quota scheme in a few respects but different in many others.

All of these market-based schemes impose obligations and then permit the obligors to trade those obligations to others. Each is designed to derive greater social benefit (affordable housing, pollution control, refugee protection) from a given level of resources. Each seeks to take account of the heterogeneity among the obligors (communities, polluters, and countries) and to turn it to social advantage. Both the New Jersey program and my refugee quota proposal are based on still-controversial norms of equitable burden-sharing, although they concern radically different goods (housing and protection from persecution) that are allocated in altogether different ways. In the housing program, both quota allocation and compliance measurement are plagued by definitional problems.

These problems, however, might not hobble a refugee-quota scheme in which strict legal definitions of "refugee" are of less practical importance. ${ }^{167}$ Such a scheme, moreover, may not require the kind of complex technocratic knowledge that pollution-control agencies must possess in order to administer an emissions-trading system effectively.

Enforceability. Once states agree to participate in a refugee-quota scheme, monitoring compliance should not be particularly difficult, as UNHCR can readily count refugees, verify their destinations, and record transactions among states. Enforcement, however, would be far more problematic. Subscribing states would presumably have the same mixed motives to comply as they do in the case of other treaty obligations. These motives balance a desire to sustain a scheme of international cooperation to which they have agreed and that they

165. See, e.g., U.S. GEN. ACCOUNTING OFFICE, GAO/RCED-95-30, AIR POLlution: AllowANCB TRADING OFFERS AN OPPORTUNITY TO REDUCE EMISSIONS AT LESS COST, ch. 3 (1994), available at http://frwebgate.access.gpo.gov/cg. . .txt\&directory=/diskb/wais/data/gao; Robert W. Hahn \& Gordon L. Hester, Marketable Permits: Lessons for Theory and Practice, 16 EcoLoGY L.Q. 361, 401-06 (1989); Peter Passell, Illinois Is Looking to Market Forces To Help Reduce Its Smog, N.Y. TIMES, Mar. 30, 1995, at D2 (noting that environmentalists believe program has succeeded beyond expectations).

166. See, e.g., DANIEL DUDEK \& JoNATHAN WIENER, OECD, JOINT IMPLEMENTATION, TRANSACTION Costs, AND Climate Change (1996); Daniel Dudek et al., Technology-Based Approaches Versus MarketBased Approaches, in GREENING INTERNATIONAL LAW 182 (Phillippe Sands ed., 1993) (discussing voluntary Climate Control accord); Stephen Kinzer, U.S. Utilities Helping Czechs To Curb Greenhouse Gases and Air Pollutants, N.Y. TMMES, Sept. 18, 1995, at A8 (noting that utilities anticipate "joint implementation" law allowing domestic pollution credits for achieving pollution reductions abroad); Peter Passell, For Utilities, New Clear-Air Plan, N.Y. TIMES, Nov. 18, 1994, at D1 (suggesting that transaction between Arizona and New York utilities may lead to global market system); Peter Passell, Yawn. A Global-Warning Alert. But This One Has Solutions, N.Y. TmEs, Feb. 13, 1997, at D2 (describing international emissions trading system to reduce greenhouse gases).

167. For discussion of refugee definitions, see supra notes $1,19$. 
believe furthers their national interest, and a desire to win or retain the approbation of actual or potential trading partners and politico-military allies, against a desire to free ride and retain their autonomy.

As with other international agreements, enforceability will depend largely on the degree to which powerful states wish to see the system implemented and are prepared to press other states to comply. I have argued that in this case, those with the greatest stakes in the scheme's success are the states that now feel obliged to accept refugees for permanent resettlement, as well as certain other nonresettlement states like Japan that might value refugee crisis insurance nonetheless. Happily, these are also the states that possess the most powerful levers for securing compliance with the quotas. Whether they would in fact use their influence for this purpose, of course, is a separate question. Once again, however, it is worth emphasizing that international cooperation is no less essential to the effectiveness of the current system.

I have proposed that the burden-sharing system initially be established on a regional basis. Participation by more states would of course be desirable and should be a goal for the future, but a scheme developed by a small number of powerful states in a region would, as noted earlier, have distinct advantages. These states could establish whatever conditions and criteria they deem necessary to protect their vital national interests. These interests would surely include their desire to discourage free rider behavior by other, nonparticipating states by penalizing their recalcitrance and rewarding their cooperation. If the scheme were successful-if it managed to diffuse refugee crises and to distribute protection burdens more broadly and fairly-other states might wish to join this market or to form markets of their own, thereby gradually enlarging the pool of burden-sharing states. ${ }^{168}$

I have also proposed that the new system of refugee protection be consensual, a feature of the current system and indeed of almost all collaborations in the international sphere. Today, states decide to protect refugees if and to the extent that they wish, for their own reasons, to do so. This is not to say, of course, that they enjoy complete freedom of action. Receiving states decide to protect refugees only after balancing a variety of considerations, including the seriousness with which they regard their obligations under the Refugee Convention. Some of their reasons are humanitarian; ${ }^{169}$ others are not. Some states may conclude that they have little choice but to acquiesce in other states' requests to participate, backed up by positive or negative inducements. The proposed system would be no different. Indeed, I have just suggested that its viability depends on the willingness of powerful receiving states to deploy these inducements, if necessary, in order to enforce the quotas.

168. For a similarly incremental approach to an incomplete market in climate change risks, see Thomas C. Heller, JoINT IMPLEMENTATION AND THE PATH TO A Climate Change REgme 11-14 (Robert Schuman Centre at the European Univ. Inst., Jean Monnet Chair Paper No. 23, 1995).

169. The Scandinavian countries, for example, do not take in refugees because of U.S. pressure; they do so out of a long, autonomous tradition of refugee protection. 


\section{B. The Quality-of-Protection Objection}

A more serious question relates not to the number of refugees who would be protected under the proposed system but to the quality of protection that would be provided in the receiving states. Under the current voluntary system, receiving states may fail to provide refugees with the full protections to which international law entitles them. Such failures, of course, are far more common with respect to the protection of those who claim asylum or other forms of temporary protection than with respect to resettled refugees, who usually become eligible for permanent legal status in short order. ${ }^{170}$ Even so, it would not be surprising if states that have traditionally volunteered to protect refugees tend to treat them better than states that agree to do so for the first time and in exchange for compensation.

This is a genuine risk, but it is not peculiar to the quota-market proposal. Indeed, the risk attaches to any move toward more universal burden-sharing that brings previously nonparticipating states into the refugee-protection system. There are several techniques for minimizing this risk; they cannot wholly eliminate it.

First, states that pay others to fulfill their quotas cannot thereby divest themselves of the duty to ensure that the rights of their quota refugees are fully protected. They should be under an independent, continuing legal responsibility to see that the states with which they deal also protect those rights. ${ }^{171}$ They could enforce this responsibility through contractual provisions, liens on receiving states' assets, and diplomatic remedies.

Second, the payments to the receiving state should not be made through an initial lump-sum transfer. Instead, the pressure for continuing compliance with human rights and other obligations can be maximized by making payments on a periodic basis. Again, the problem of ensuring that resources that the donor provides for refugee protection are in fact used for that purpose, rather than being drained off by corruption or inefficient administration, is a ubiquitous one, especially in the impoverished regions in which many refugee crises arise. It is not at all peculiar to the proposed burden-sharing scheme.

Third, the administering agency, whether it be UNHCR or another, should be given wide-ranging authority to monitor and to publicize the treatment of resettled refugees in light of humanitarian standards. Paying states must ensure that the agency receives the resources it needs to carry out its essential monitoring and reporting functions. By drawing more states into the protection system and by imposing on transferors as well as transferees a continuing responsibility for the proper expenditure of protection funds, the proposed system should increase support for the agency's activities.

170. The efforts by Zaire and Burundi to force Hutu refugees to return to Rwanda are tragic examples of the failure to protect those seeking temporary protection. See McKinley, supra note 79.

171. This responsibility could be analogized to a company's continuing liability-imposed by contract, statute, or common law-for certain risks associated with particular assets it sells to another. 
The proposed expansion of the refugee-protection system beyond the traditional receiving states raises a related quality problem. The quota transfers permitted under a market system increase the probability that a refugee will end up being offered protection in a state in which she simply does not want to be. The states that the market newly draws into the system are likely to be poorer, more geographically isolated, ethnically different, and have different social policies than the traditional receiving states.

A refugee offered protection by a relatively unattractive state is placed in an unenviable position. She may have few options, all of them undesirable. She can reject the offer and remain where she is, in perhaps indefinite limbo, hoping that something better comes along. She can try to return home, which may be dangerous or even suicidal. Or she can accept the offer and receive protection in a country in which she thinks she will be unhappy.

Under the current system, a refugee confronts essentially the same options, with the difference being that there is a higher ex ante probability that the offering state will be an attractive one in which to live, temporarily or permanently. The refugee's options are limited because her rights under international law are limited. She is entitled only to non-refoulement and the other basic protections accorded by the Refugee Convention. She has no right to receive those protections in any particular state. Many refugees struggle, against great odds, to move from the state that initially offered them protection to one in which they prefer to live. Many succeed in doing so. Refugees, however, have no rights qua refugees to be protected in one state rather than in another. To create such a right would certainly reduce the willingness of states to grant protection, and it is almost inconceivable that the international community will ever do so.

A system of quotas (marketable or not) is designed to draw more states into the refugee-protection system and to increase the number of refugees receiving protection, but the quality of this protection may be reduced if the newly participating states are permitted to be less hospitable to refugees. This tension between the total amount of protection (in the sense of the number receiving it) and the quality of protection enjoyed by those who receive it transcends the marketable quota proposal; it applies, mutatis mutandis, to any reform that seeks to broaden refugee burden-sharing.

I believe that the paramount goal for refugee policy should be to maximize the number of individuals receiving basic protection against threats to their lives and freedoms. ${ }^{172}$ Maximizing the quality of life enjoyed by those who receive that basic protection is highly desirable, of course, but it remains secondary to this primary purpose. Those who hold different normative priorities will view the proposal less favorably, but they will be hard pressed, I believe, to devise

172. This goal is recognized in section 243(h) of the Immigration and Nationality Act, 8 U.S.C. $\S$ 1253(h) (1994), which implements article 33 of the 1951 Refugee Convention. Section 243(h) provides that "the Attorney General shall not deport or return any alien . . . to a country if the Attorney General determines that such alien's life or freedom would be threatened in such country on account of race, religion, nationality, membership in a particular social group, or political opinion." Id. 
a better one.

\section{The Commodification Objection}

A final objection is directed not at the idea of quotas per se but at the moral implications of a system of marketable refugee quotas. This objection holds that such a market would allow and encourage states to traffic in human beings-and desperately vulnerable human beings at that-and that this offends common morality. ${ }^{173}$

For four reasons, my response to this objection is brief. First, the objection is a familiar one. It is made whenever the market is used to allocate scarce goods or activities-organ transplants, education, environmental controls, communications spectra, childbearing, and low-cost housing, to name a few examples-that have traditionally been allocated, at least ostensibly, through administrative or other "nonmarket" mechanisms. ${ }^{174}$

Second, the commodification objection implies that the relevant comparison is between a callous market-based system that would arbitrarily allocate refugees to diverse places and fates and a more rational system that allocates them according to some exalted principle of justice. In reality, of course, the existing refugee system does not even pretend to approach such an ideal. Rather, it is a system that-in common practice, if not in law-allows states of first asylum to decide whether and how to protect the individuals who manage to reach them and allows a handful of other states to select the small number of refugees whom they will accept for resettlement, usually based on their judgments about the refugees' prospects for assimilation. This system leaves the majority of refugees to languish indefinitely in dehumanizing, squalid camps or to be repatriated to conditions of possible persecution and almost certain suffering. Given the harsh reality of a dehumanizing status quo, a commodification objection to the proposed reform seems quite beside the point.

Third, the proposed system is perfectly compatible with whatever regulatory protections and market constraints are thought conducive to securing overriding public values. This is not to say, however, that any such constraint could be imposed without sacrificing other goals, including states' willingness to participate in the burden-sharing system. ${ }^{175} \mathrm{Here}$, as elsewhere, the market

173. For an elaboration of such an argument in the context of rent control, see Margaret Jane Radin, Market-Inalienability, 100 HARV. L. REV. 1849, 1878, 1918 (1987); Margaret Jane Radin, Residential Rent Control, 15 PHIL. \& PUB. AFF. 350 (1986). For a response to Radin, see Richard A. Epstein, Rent Control and the Theory of Efficient Regulation, 54 BROOK. L. REV. 741, 770-74 (1988).

174. For classic discussions of alternative decision processes for allocating such goods, see Guido

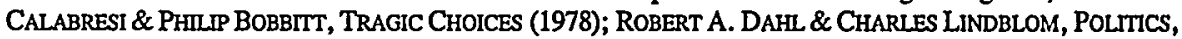
ECONOMICS, AND WELFARE (1976). The phrase "at least ostensibly" and the scare quotes around "nonmarket" are intended to convey a recognition that these other processes, including politics and legal structures, usually conceal rather than eliminate the market's operation. This fact is in accord with public choice theory and with empirical studies in areas as diverse as campaign finance, interest group behavior, the regulatory process, judicial elections, and litigation.

175. For example, a requirement that interstate transactions be "identity-blind," see supra notes 145-48 and accompanying text, might discourage some ethnically homogeneous states from participating. 
exacts its price; there is no free lunch. But it is to say that we can and should seek an optimal mix of the conflicting values.

Finally, the commodification argument would fail even on its own terms if the market-based system actually succeeded in protecting more refugees, with a quality of protection no worse, and at a lower cost, than in the current system. Although new schemes seldom work exactly as planned, and prudence thus dictates caution on the part of reformers (including confining the proposal to a regional, consensual demonstration), I have adduced strong reasons to believe that the proposed scheme could indeed produce each of these advantages.

\section{CONCLUSION}

The need for improved refugee protection is both manifest and growing. The existing system, jerry-built to address conditions that have changed dramatically since its inception, exhibits a number of major flaws. At the most general level, the two most important flaws include a failure to furnish at least temporary protection to a large number of refugees who desperately need it and an unfair distribution of burdens among states able to provide protection. The maintenance of even this unsatisfactory system ultimately depends on the willingness of the relatively powerful industrial nations to use their leverage-their array of carrots and sticks-to induce the first-asylum states to offer temporary protection and, where permanent protection is necessary, to arrange for a limited number of resettlement slots in their own countries.

Equitable burden-sharing among states is a noble vision but not a new one. What is required to instantiate it is a system of norms, incentives, and institutions that can mobilize the necessary protection resources from states that will always be reluctant to commit them, especially if they believe that the protection will be permanent, not temporary. No system can eliminate this reluctance; it is endemic to states' narrow conceptions of their national selfinterest. But the refugee burden-sharing scheme-by proposing a regionallybased, consensual arrangement combining a quota system that distributes refugee burdens among the wealthier states with a market option that can redistribute protection resources to other states that can more effectively use them to harbor more refugees-promises to increase the overall level and quality of protection. Like many promises, its hopes might not be fully realized, but even so it could hardly leave refugees worse off than they are now. In view of both the deplorable status quo and the potential for human rights gains, can we afford not to try? 
. 